\title{
Wskaźniki morfometryczne w geomorfologii tektonicznej
}

\author{
Morphometric indices in tectonic geomorphology
}

\author{
Milena Różycka \\ Instytut Geografii i Rozwoju Regionalnego, Uniwersytet Wrocławski; milena.rozycka@uwr.edu.pl
}

\begin{abstract}
Zarys treści: Geomorfologia tektoniczna jest dynamicznie rozwijającą się dziedziną nauki - głównie za sprawą nowych możliwości badawczych, które pojawiły się wraz z rozwojem narzędzi udostępnianych za pośrednictwem Geograficznych Systemów Informacyjnych (GIS) oraz z wprowadzeniem cyfrowych zestawów danych wysokościowych. Dzięki temu rozwijany jest przede wszystkim ilościowy kierunek tych badań. Niniejsza praca ma charakter przeglądowy. Zestawiono w niej, podzielono oraz omówiono wskaźniki morfometryczne wykorzystywane w badaniach nad młodą aktywnością tektoniczną obszarów, zwracając jednocześnie uwagę na ograniczenia interpretacyjne związane z ich wykorzystywaniem. Przegląd literatury uwzględnia opracowania zarówno polskie, jak i zagraniczne opublikowane w latach 2000-2015.
\end{abstract}

Słowa kluczowe: geomorfologia tektoniczna, wskaźniki morfometryczne, aktywność tektoniczna

\begin{abstract}
New research possibilities that emerged from the development of Geographic Information Systems (GIS) and digital topography underpin the growth of tectonic geomorphology, mainly in respect to quantitatively oriented investigations. This paper presents a review of morphometric parameters that have been applied in morphotectonic studies in Poland and worldwide and is essentially based on papers published from 2000 to 2015 . Classification of tectonic activity indicators is presented, as well as limitations in their interpretation are discussed.
\end{abstract}

Key words: tectonic geomorphology, morphometric indices, tectonic activity

\section{Wprowadzenie}

Ilościowy kierunek badań w geomorfologii jest obecnie prężnie rozwijany, o czym świadczy duża liczba opracowań morfometrycznych bazujących na analizie cyfrowych modeli wysokościowych i ich pochodnych, a prowadzonych z wykorzystaniem metod i narzędzi udostępnianych za pośrednictwem oprogramowania GIS (Zwoliński 2010). Wśród tych prac licznie reprezentowane są te $z$ zakresu geomorfologii tektonicznej, badającej powierzchniowe skutki procesów tektonicznych, a ilościowy wymiar takich badań został podkreślony w syntezach tej dziedziny autorstwa Burbanka i Andersona (2001, 2011) oraz Bulla (2007).

Opracowaniom z zakresu morfotektoniki już wcześniej, przed rozwojem metod komputerowych, towarzyszyły zwykle studia morfometryczne, a ilościowej analizy form rzeźby i cech systemu rzecznego dla potrzeb określania stopnia aktywności tektonicznej obszarów dokonywano najczęściej na podstawie map topograficznych (np. Krzyszkowski i in. 1995, Zuchiewicz 1995, Sroka 1997, Talling i in. 1997). Użyteczność środowiska GIS oraz cyfrowych zestawów danych wysokościowych w badaniach morfotektonicznych jest często podkreślana we współczesnej literaturze przedmiotu (Troiani, Della Seta 2008, Azañón i in. 2012, Brzezińska-Wójcik 2013, Gao i in. 2013).

Niniejsze opracowanie ma na celu przegląd wskaźników morfometrycznych obecnie wykorzystywanych w badaniach z zakresu geomorfologii tektonicznej w Polsce i na świecie. Dotyczy ono zasadniczo lat 2000-2015, choć całkowite pominięcie opracowań z lat wcześniejszych nie jest możliwe. W artykule dokonano zestawienia i opisu wskaźników morfometrycznych, przedstawiono 
propozycję ich podziału, a także omówiono główne ograniczenia interpretacyjne związane $\mathrm{z}$ ich wykorzystywaniem.

\section{Podział wskaźników aktywności tektonicznej}

Liczba wskaźników wykorzystywanych w ilościowych badaniach z zakresu geomorfologii tektonicznej jest znaczna, zasadne zatem wydaje się dokonanie ich podziału. Próbę taką podjęli wcześniej Pánek (2004) oraz Brzezińska-Wójcik (2013). Pánek (2004) wyróżnił osiem kategorii wskaźników: zmienne hipsometryczne, wskaźniki spadku i energii rzeźby, charakterystyki sieci rzecznej, wskaźniki odnoszące się do profili podłużnych rzek, przekrojów poprzecznych dolin, kształtu zlewni, morfologii frontów górskich oraz parametry uzyskiwane $\mathrm{z}$ cyfrowych modeli wysokościowych. Ostatnia $\mathrm{z}$ wydzielonych grup wskazuje zatem nie tyle na cechy rzeźby lub systemu rzecznego, do których poszczególne wskaźniki się odnoszą, co na źródło danych do obli- czeń. Autor wyróżnia w niej między innymi autokorelacje prowadzone na zestawie danych wysokościowych, a pozwalające na określenie stopnia anizotropii rzeźby (Jordan 2003, Jordan i in. 2003). Wydaje się jednak, że sama autokorelacja jest sposobem prowadzenia analizy, pozwalającym na wykrycie pewnych zależności przestrzennych, nie zaś wskaźnikiem samym w sobie. Należy zauważyć, że zaproponowany przez autora ponad 10 lat temu podział nie jest rozłączny i jest częściowo nieaktualny. Dzięki dynamicznemu rozwojowi metod i narzędzi systemów informacji geograficznej oraz cyfrowych modeli wysokościowych wskaźniki te liczone są już przede wszystkim z ich wykorzystaniem i na bazie cyfrowego zestawu danych wysokościowych. Podział zaproponowany przez Pánka (2004) powstał w czasach, gdy metody i narzędzia GIS były dopiero wprowadzane na szerszą skalę.

Podział zaproponowany przez Brzezińską-Wójcik (2013) odnosi się jedynie do tych wskaźników morfometrycznych, które autorka sama wykorzystała w badaniach i obejmuje trzy zasadnicze grupy: wskaźniki opisujące wysokości w zlewniach, wskaźniki charakteryzujące geometrię zlewni oraz tzw. współczynniki liniowe, do któ-

Tabela 1. Wskaźniki morfometryczne wykorzystywane w badaniu aktywności tektonicznej obszarów (objaśnienie użytych symboli w tekście)

Table 1. Morphometric indices of tectonic activity (explanation of symbols used in the table in the text)

\begin{tabular}{|c|c|c|}
\hline Wskaźnik & Wzór & Źródło \\
\hline \multicolumn{3}{|c|}{ Wskaźniki odnoszące się do morfologii frontów górskich } \\
\hline Wskaźnik krętości & $\mathrm{S}_{\mathrm{mf}}=\mathrm{L}_{\mathrm{mf}} / \mathrm{L}_{\mathrm{s}}$ & Bull 1977, Bull, McFadden 1977 \\
\hline Wskaźnik rozczłonkowania & $\mathrm{F} \%=\mathrm{L}_{\mathrm{f}} / \mathrm{L}_{\mathrm{s}}$ & Wells i in. 1988 \\
\hline Wskaźnik odstępu & $\mathrm{R}=\mathrm{W} / \mathrm{S}$ & Wallace 1978 \\
\hline \multicolumn{3}{|c|}{ Wskaźniki odnoszące się do geometrii dolin rzecznych } \\
\hline Wskaźnik szerokości dna - wysokości zboczy doliny & $\mathrm{v}_{\mathrm{f}}=2 \mathrm{~V}_{\mathrm{fw}} /\left[\left(\mathrm{E}_{\mathrm{ld}}-\mathrm{E}_{\mathrm{sc}}\right)+\left(\mathrm{E}_{\mathrm{rd}}-\mathrm{E}_{\mathrm{sc}}\right)\right]$ & Bull 1977, Bull, McFadden 1977 \\
\hline Wskaźnik kształtu przekroju poprzecznego doliny & $\mathrm{V}=\mathrm{A}_{\mathrm{v}} / \mathrm{A}_{\mathrm{c}}$ & Mayer 1986 \\
\hline \multicolumn{3}{|c|}{ Wskaźniki kształtu zlewni } \\
\hline Wskaźnik wydłużenia & $\mathrm{R}_{\mathrm{e}}=2(\mathrm{~A} / \pi)^{0,5} / \mathrm{L}$ & Schumm 1956 \\
\hline (Planimetryczny) wskaźnik kształtu zlewni & $\mathrm{B}_{\mathrm{s}}=\mathrm{B}_{\mathrm{l}} / \mathrm{B}_{\mathrm{w}}$ & Ramírez-Herrera 1998 \\
\hline Wskaźnik kształtu zlewni & $\mathrm{Rf}=\mathrm{A} / \mathrm{L}^{2}$ & Horton 1932 \\
\hline Wskaźnik kształtu zlewni & $\mathrm{B}_{\mathrm{s}}=\mathrm{L}^{2} / \mathrm{A}$ & Singh 1988 \\
\hline Wskaźnik lemniskaty & $\mathrm{k}=\pi \mathrm{L}^{2} / 4 \mathrm{~A}$ & Chorley 1957 \\
\hline Wskaźnik kolistości zlewni & $\mathrm{RC}=4 \pi \mathrm{A} / \mathrm{P}^{2}$ & Miller 1953 \\
\hline Wskaźnik zwartości zlewni & $\mathrm{B}_{c}=\mathrm{P} / \mathrm{A}$ & Engstrom 1989 \\
\hline \multicolumn{3}{|c|}{ Wskaźniki asymetrii zlewni } \\
\hline Wskaźnik asymetrii zlewni & $\mathrm{AF}=100\left(\mathrm{~A}_{\mathrm{r}} / \mathrm{A}\right)$ & Hare, Gardner 1985 \\
\hline Czynnik poprzecznej asymetrii topograficznej & $\mathrm{T}=\mathrm{Da} / \mathrm{Dt}$ & Cox 1994 \\
\hline \multicolumn{3}{|c|}{ Wskaźniki wysokościowe zlewni } \\
\hline Całka hipsometryczna (uproszczenie) & $\mathrm{hi}=\left(\mathrm{H}_{\text {mean }}-\mathrm{H}_{\min }\right) /\left(\mathrm{H}_{\max }-\mathrm{H}_{\min }\right)$ & Strahler 1952 \\
\hline Wskaźnik rzeźby & $\mathrm{Rh}=\mathrm{H} / \mathrm{L}$ & Schumm 1956 \\
\hline Wskaźnik wysokości względnych & $\mathrm{Rhp}=\mathrm{H} / \mathrm{P}$ & Melton 1957,1958 \\
\hline \multicolumn{3}{|c|}{ Wskaźniki odnoszące się do cech systemu rzecznego } \\
\hline Wskaźnik bifurkacji & $\mathrm{R}_{\mathrm{b}}=\mathrm{N}_{\mathrm{u}} / \mathrm{N}_{\mathrm{u}+1}$ & Horton 1932 \\
\hline Wskaźnik gęstości sieci drenażu & $\mathrm{D}_{\mathrm{d}}=\Sigma \mathrm{L} / \mathrm{A}$ & Neumann 1900, za Horton 1932 \\
\hline Wskaźnik liczby cieków & $\mathrm{F}=\mathrm{N}_{\mathrm{u}} / \mathrm{A}$ & Horton 1932 \\
\hline Wskaźnik udziału cieków pierwszego rzędu & $\mathrm{N}_{1} / \mathrm{N}$ & Zuchiewicz 1980, 1989 \\
\hline \multicolumn{3}{|c|}{ Wskaźniki odnoszące się do spadku cieków } \\
\hline Wskaźnik długości - spadku rzeki & $\mathrm{SL}=(\Delta \mathrm{H} / \Delta \mathrm{L}) \mathrm{L}$ & Hack 1973 \\
\hline Wskaźnik stromości & $\mathrm{S}=\mathrm{k}_{\mathrm{s}} \mathrm{A}^{-\theta}$ & Snyder $\mathrm{i}$ in. 2000 , Wobus $\mathrm{i}$ in. $2006 \mathrm{a}, \mathrm{b}$ \\
\hline
\end{tabular}


rych zaliczono wskaźnik krętości czoła masywu górskiego $\mathrm{S}_{\mathrm{mf}}$ oraz wskaźnik szerokości dna - wysokości zboczy doliny $\mathrm{V}_{\mathrm{f}}$ (Bull 1977, Bull, McFadden 1997).

Przedstawiony w niniejszym opracowaniu podział (Tabela 1) obejmuje siedem kategorii wskaźników. Dwie pierwsze tworzone są przez wskaźniki odnoszące się do morfologii frontów górskich oraz do cech geometrycznych dolin cieków, które fronty te rozcinają. Trzy kolejne reprezentowane są przez miary liczone dla zlewni jako podstawowych pól odniesienia. Są to wskaźniki kształtu, asymetrii oraz wysokości. Jak podkreśla Brzezińska-Wójcik (2013: 35-36) „współczynniki morfometryczne charakteryzujace zlewnie dość dobrze ilustruja zależność systemu rzecznego od skali pionowych ruchów wypiętrzajacych". Na ostatnie dwie kategorie składają się wskaźniki odnoszące się do cech systemu rzecznego oraz do spadku cieków.

Morfologia frontów górskich zależna jest od kształtu zlewni rozwijających się na ich zapleczach, a wskaźnikiem łączącym te dwie domeny jest wskaźnik odstępu $\mathrm{R}$ (Wallace 1978). W niniejszym podziale włączony on został do pierwszej z wyróżnionych kategorii wskaźników (tabela 1), jako że wykorzystywany jest do oceny aktywności tektonicznej frontów górskich (Burbank, Anderson 2011), podczas gdy analiza cech geometrycznych zlewni (w tym ich wydłużenia, branego pod uwagę przy obliczaniu wskaźnika R), może wykraczać poza wąską, krawędziową strefę masywów górskich (Jayappa i in. 2012, Brzezińska-Wójcik 2013).

Prezentowane zestawienie (Tabela 1) pozwala zauważyć, że zdecydowana większość wskaźników wykorzystywanych w ilościowych badaniach z zakresu geomorfologii tektonicznej odnosi się do cech rzeźby fluwialnej oraz systemu rzecznego, jako tych elementów systemu geomorfologicznego, które są szczególnie czułe na zaburzenia wywołane mobilnością tektoniczną podłoża.

\section{Przegląd wskaźników aktywności tektonicznej}

\section{Wskaźniki odnoszące się do morfologii frontów górskich}

Stopień aktywności tektonicznej w strefie krawędziowej gór może być wyrażony wskaźnikiem krętości czoła masywu górskiego (ang. mountain front sinuosity index) (Bull 1977, Bull, McFadden 1977). Jest to parametr niemianowany, zdefiniowany jako stosunek rzeczywistej długości podstawy progu tektonicznego mierzonej wzdłuż wyraźnego załomu stokowego od punktu A do punktu B ( $\left.\mathrm{L}_{\mathrm{mf}}\right)$ do długości odcinka prostego łączącego te dwa punkty $\left(\mathrm{L}_{\mathrm{s}}\right)$ według wzoru:

$$
\mathrm{S}_{\mathrm{mf}}=\mathrm{L}_{\mathrm{mf}} / \mathrm{L}_{\mathrm{s}}
$$

Zastosowanie samego wskaźnika krętości w geomorfologii nie ogranicza się tylko i wyłącznie do progów o założeniach tektonicznych. Jest on także obliczany dla progów denudacyjnych (np. Migoń, Zwiernik 2006), a także dla koryt rzecznych (Brice 1964), stanowiąc podstawę do podziału tych jednonurtowych na proste, kręte i meandrowe.

Interpretacja tego wskaźnika opiera się na założeniu, że progi wzdłuż uskoków aktywnych tektonicznie wykazują przebieg zbliżony do prostoliniowego, podczas gdy obniżenie tej aktywności sprzyja erozyjnemu rozcinaniu progu, co prowadzi do wzrostu jego krętości. Wobec powyższego należy stwierdzić, że parametr ten wyraża stosunek pomiędzy intensywnością pionowych ruchów wypiętrzających a efektywnością zewnętrznych procesów denudacyjnych.

Progi tektoniczne wzdłuż uskoków aktywnych powinny odznaczać się niskimi wartościami wskaźnika, bliskimi jedności. Jak podkreślają Verrios i in. (2004), Badura i in. (2007) oraz Brzezińska-Wójcik (2013), w literaturze zwykło się przyjmować - za Rockwellem i in. (1985) oraz Wellsem $\mathrm{i}$ in. (1988) - że wartości $\mathrm{S}_{\mathrm{mf}}$ mniejsze niż 1,4 cechują strefy aktywne tektonicznie. Stosunkowo często przywoływany jest również podział aktywności tektonicznej progów według Bulla $(1977,1978)$ oraz Bulla i McFaddena (1977) opracowany dla prowincji Basin and Range w południowo-zachodniej części USA. Zgodnie z tą klasyfikacją wartości wskaźnika krętości z przedziału 1,0-1,6 odpowiadają krawędziom aktywnym tektonicznie, a te z przedziałów $1,4-3,0$ oraz od 1,8 do nawet powyżej 5,0 charakteryzują krawędzie o odpowiednio niskiej oraz względnie znikomej aktywności (por. np. Cuong, Zuchiewicz 2001a, b, Badura i in. 2003, 2007, Brzezińska-Wójcik i in. 2010a, b). Rozłączne przedziały wartości wskaźnika $\mathrm{S}_{\mathrm{mf}}$ dla trzech klas aktywności tektonicznej progów podaje Bull (2007), wyróżniając progi o aktywności wysokiej $(1,0-1,5)$ i umiarkowanej $(1,5-3,0)$ oraz nieaktywne (od 3,0 do powyżej 10). Jeszcze bardziej uproszczony podział przedstawiają Burbank i Anderson (2011). Uwzględniają w nim progi aktywne tektonicznie o wartościach wskaźnika bliskich 1,0 oraz te o względnie niskiej mobilności wyrażonej wartościami $\mathrm{S}_{\mathrm{mf}}$ wzrastającymi do 2,0 i więcej.

Choć część autorów określa stopień aktywności tektonicznej badanych progów odnosząc się bezpośrednio do pierwotnej klasyfikacji autorów amerykańskich (Bull 1977, 1978, Bull, McFadden 1977) (por. np. Cuong, Zuchiewicz, 2001a, b, Brzezińska-Wójcik, Hołub 2007, Sarp i in. 2011), to Ranoszek (2001) zwraca uwagę na problem aplikacyjności metod morfometrycznych opracowanych w zupełnie innym obszarze, w tym również wskaźnika krętości w odniesieniu do własnego obszaru badań, którym były Sudety. W tym kontekście wychodzi z wnioskiem, że uzyskane wartości wskaźnika, w bardzo niewielkim stopniu zresztą zróżnicowane, nie powinny być przypisywane klasom aktywności tektonicznej sensu Bull i McFadden (1977) wprost i że ,,(...) samo zróżnicowanie krętości powinno być rozważone $w$ przedziale, w którym ów wskaźnik występuje (...)" (Ranoszek 2001: 43-44). Niejako w opozycji do tego stwierdzenia stoi zda- 
nie z pracy Aty (2008: 162, tłumaczenie własne), który motywuje przyjęcie klasyfikacji wyżej wymienionych autorów tak: „Klasyfikacja ta została przyjęta, ponieważ udowodniono, że ma praktyczne zastosowanie dla obszarów o różnych uwarunkowaniach geologicznych". Autor nie powołuje się w tym miejscu jednak na konkretne źródła.

W pracach niektórych autorów podstawą do wydzielenia własnych przedziałów dla klas różnej aktywności tektonicznej progów (Silva i in. 2003, El Hamdouni i in. 2008, Dehbozorgi i in. 2010, Brzezińska-Wójcik 2013) stała się analiza rozkładu statystycznego uzyskanych wartości wskaźnika krętości.

Liczba polskich opracowań morfotektonicznych, w których uwzględniano omawiany wskaźnik w analizowanym przedziale czasu jest stosunkowo niewielka. Zuchiewicz (2000), Brzezińska-Wójcik i in. (2002, 2010a, b) oraz Badura i in. (2003) powołują się na publikacje z lat wcześniejszych, w których wskaźnik ten, obok wielu innych parametrów morfometrycznych, uwzględniano w badaniach nad mobilnością tektoniczną górskich i wyżynnych obszarów Polski. W tym czasie, jak zauważają Brzezińska-Wójcik i in. (2010b), zmieniły się źródła danych do pomiarów morfometrycznych, a najczęściej wykorzystywane $\mathrm{w}$ tych celach mapy topograficzne zostały zastąpione cyfrowymi modelami wysokościowymi. Na ich podstawie wskaźnik krętości, jako składowa szczegółowych studiów morfometrycznych, obliczony został dla progu morfologicznego rozciągającego się wzdłuż sudeckiego uskoku brzeżnego na odcinku najpierw od Dobromierza po Złoty Stok (Badura i in. 2003), a później na całej długości tego progu od Złotoryi po Jesenik (Badura i in. 2007, 2008). W obu przypadkach autorzy przedstawili jego pojedynczą wartość, obliczoną każdorazowo do całego badanego odcinka, bez jego podziału na mniejsze fragmenty. Wartość ta wyniosła odpowiednio 1,054 oraz 1,051, mieszcząc się tym samym w pierwszej klasie aktywności tektonicznej progów sensu Bull i McFadden (1977). Autorzy odnieśli się jednocześnie do wcześniejszej pracy Krzyszkowskiego i in. (1995), w której pokazano zróżnicowanie wartości wskaźnika krętości dla poszczególnych segmentów progu różniących się cechami morfologicznymi oraz geologicznymi. Podział progu na segmenty, zwłaszcza w odniesieniu do struktur o znacznej rozciągłości i dużym zróżnicowaniu litologicznym, jest rekomendowany (Burbank, Anderson 2011), a kryteria, na bazie których powinien być dokonany, wymienione zostały ponad 25 lat temu w pracy Wellsa $\mathrm{i}$ in. (1988). Podejście takie jest w literaturze często stosowane (Cuong, Zuchiewicz 2001a, b, Brzezińska-Wójcik $i$ in. 2010a, Pérez-Peña i in. 2010, Wiwegwin i in. 2011, Azanón i in. 2012, Melosh, Keller 2013), a w odniesieniu do progu związanego z przebiegiem sudeckiego uskoku brzeżnego, a także innych progów tektonicznych w polskiej i czeskiej części Sudetów, zaaplikowane zostało przez Ranoszka (2001). Taki sposób obliczania krętości progów tektonicznych przyjęty został także w odniesieniu do Roztocza Tomaszowskiego (Brzezińska-Wójcik
2002, Brzezińska-Wójcik, Hołub 2007), ukraińskiej części Roztocza (Brzezińska-Wójcik i in. 2010a) oraz całego annopolsko-lwowskiego segmentu pasa wyżynnego (Brzezińska-Wójcik 2013).

Liczba opracowań zagranicznych, w których stosowano wskaźnik krętości czoła masywu górskiego do oceny aktywności tektonicznej obszaru jest dla rozpatrywanego przedziału czasowego znacznie większa, a na poszczególne pozycje powołuje się Brzezińska-Wójcik (2013) przy okazji szczegółowego omawiania zakresów wartości, jakie wskaźnik ten przyjmuje. Podobne zestawienie przedstawili również Shtober-Zisu i in. (2008).

Niewątpliwą zaletą wskaźnika $\mathrm{S}_{\mathrm{mf}}$ jest duża prostota obliczeniowa, jednak jego użyteczność interpretacyjna nie jest pozbawiona pewnych ograniczeń. Wskaźnik krętości nie uwzględnia w żaden sposób uwarunkowań litologicznych, które decydują o odporności skał na procesy niszczące. W idealnym przypadku powinien być więc liczony dla progów zbudowanych z jednakowego typu skał, co w praktyce nie jest łatwe do osiągnięcia. Należy mieć zatem na uwadze, że zróżnicowanie tego parametru w obszarach o odmiennej budowie geologicznej może odzwierciedlać nie tylko aktywność tektoniczną, lecz także cechy podłoża. Wobec powyższego właściwa wydaje się pogłębiona analiza uzyskanych wartości wskaźnika w odniesieniu do cech litologicznych (Brzezińska-Wójcik 2013).

Pewną dozą subiektywności może być obarczone wyznaczanie podstawy progu tektonicznego, zwłaszcza, gdy dokonuje się tego w oparciu o mapy topograficzne o większym cięciu poziomicowym, np. 30-metrowym (Bull 2007). Na podstawie obrazu poziomicowego trudno niekiedy też wnioskować o pochodzeniu niektórych elementów rzeźby w krawędziowej strefie gór. Zwiększa to ryzyko błędnych interpretacji, które mogą - poprzez błędne poprowadzenie granicy pomiędzy masywem górskim a jego przedpolem - przełożyć się na nieprawidłowe wartości wskaźnika. Przykład taki przedstawia Bull (2007). Dotyczy on mylnego włączenia silnie rozczłonkowanych powierzchni starych stożków napływowych jeszcze do krawędziowej strefy gór, zamiast przypisania ich do obszaru przedpola. Rangę tego problemu w znaczący sposób zmniejsza zastosowanie wysokorozdzielczych danych wysokościowych pochodzących z lotniczego skaningu laserowego (LiDAR).

Problematyczne jednak wciąż pozostaje wyznaczenie tej granicy $\mathrm{w}$ strefie rozcięć dolinnych na progach mało aktywnych, a przez to wyraźnie już przekształconych przez erozję. Doliny takie mogą odznaczać się znaczną szerokością dna w strefie przykrawędziowej, kontynuującą się daleko w górę rzeki. Taka sytuacja wymaga odpowiedzi na pytanie, do jakiej odległości w górę rozcięcia dolinnego doprowadzić krzywą $\mathrm{L}_{\mathrm{mf}}$, aby nie uzyskać nadmiernie dużej wartości licznika w tym wskaźniku poprzez włączanie do niego długości podstawy zboczy dolinnych. Zalecane jest, aby dystans ten przyjmował stałą wartość (Bull 2007). 
Zdarza się również, że wartości wskaźnika krętości nie odzwierciedlają obecnej aktywności tektonicznej progu, np. wysoka krętość może cechować i progi rozciągające się wzdłuż uskoków obecnie aktywnych (Burbank, Anderson 2011). Sytuacja taka może dotyczyć przypadku, w którym dochodzi do odnowienia aktywności starych uskoków, wzdłuż których zdążyły się już rozwinąć krawędzie o krętym przebiegu. Aktywność ta może nie być jednak wystarczająco intensywna, lub też zbyt współczesna, by „odnowić” prostoliniowy przebieg progu przy jego podstawie. Ponieważ zmiany w krętości przebiegu frontu górskiego dokonują się w długim czasie, wskaźnik ten powinien stanowić uzupełnienie dla innych wskaźników morfometrycznych, bazujących na elementach systemu geomorfologicznego reagujących na zmiany tektoniczne w podłożu w krótszym czasie, przede wszystkim elementach morfologii fluwialnej.

Pewnej słabości w obliczaniu wskaźnika krętości dla progów o specyficznym przebiegu doszukali się autorzy słowaccy, wychodząc jednocześnie z propozycją modyfikacji sposobu obliczania tego parametru, a ściślej mówiąc, pomiaru mianownikowej wartości $\mathrm{L}_{\mathrm{s}}$ (Vojtko i in. 2011a, b). Dotyczy to sytuacji, w której zasadniczy przebieg frontu górskiego nie nawiązuje do linii prostej, lecz łukowato zmienia kierunek na dystansie kilku kilometrów. Wówczas odnoszenie rzeczywistej długości podstawy progu do długości odcinka prostego mogłoby prowadzić do mylnych interpretacji i wniosków. Dlatego też wspomniani autorzy długość tę odnoszą do długości łuku elipsy najlepiej aproksymującego zasadniczy przebieg progu tektonicznego.

Parametrem określającym stopień erozyjnego rozcięcia frontu górskiego i jego podziału na lica trójkątne, a więc degradacji postępującej w warunkach względnego spokoju tektonicznego, jest wskaźnik F\% (faceting parameter, facet index). Nie doczekał się on swojego odpowiednika w polskiej terminologii, stąd proponuje się określić go mianem wskaźnika rozczłonkowania progu tektonicznego. Wskaźnik ten definiowany jest jako stosunek sumarycznej długości podstawy lic trójkątnych występujących wzdłuż danego progu, bądź badanego segmentu $\left(\mathrm{L}_{\mathrm{f}}\right)$, do całkowitej jego długości liczonej wzdłuż linii prostej $\left(\mathrm{L}_{\mathrm{s}}\right)$, według wzoru:

$$
\mathrm{F} \%=\mathrm{L}_{\mathrm{f}} / \mathrm{L}_{\mathrm{s}} .
$$

Wysokie wartości wskaźnika odpowiadają progom o wysokim stopniu aktywności tektonicznej i niewielkim stopniu rozczłonkowania, podczas gdy wartości niskie typowe są dla progów mało aktywnych, a przez to w znacznym już stopniu przekształconych przez erozję prowadzącą do zmniejszania szerokości podstawy lic trójkątnych.

Tego typu wskaźnik zastosowano już w latach 80 . i 90. XX w. (Wells i in. 1988, Ramírez-Herrera 1998), a w nowszych publikacjach - bez powołania na wcześniejsze prace - był on stosowany do oceny stopnia aktywności progów tektonicznych w Iranie (Bafti 2009, Jami i in.

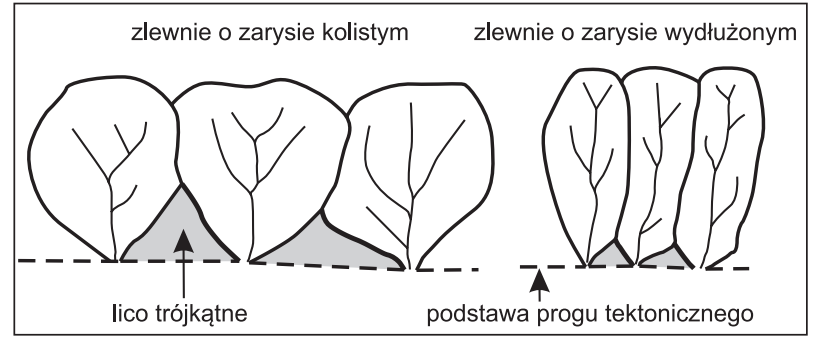

Ryc. 1. Kształt zlewni na zapleczach progów tektonicznych a szerokość podstaw lic trójkątnych i odległość pomiędzy punktami zamykającymi zlewnie (Mayer 1986, Burbank, Anderson 2001, zmienione)

Fig. 1. Shape of drainage basins in relation to the base width of triangular facets and spacing between basin outlets along the mountain front (Mayer 1986, Burbank, Anderson 2001, modified)

2013, Samadi 2014, Khalaj 2015). Wskaźnik F\% nie jest obecnie często wykorzystywany w ilościowych badaniach z zakresu geomorfologii tektonicznej.

Cechy geometryczne zlewni potoków rozcinających progi tektoniczne przekładają się bezpośrednio na wielkość i kształt lic trójkątnych, a także odległości pomiędzy punktami, które zlewnie te zamykają (Mayer 1986, Burbank, Anderson 2011). Bardziej kolisty zarys zlewni, typowy dla obszarów o mniejszej aktywności tektonicznej, odpowiada szerszym podstawom lic trójkątnych, a tym samym większym odległościom pomiędzy punktami, w których cieki rozcinają podstawę progu (ryc. 1). Odległość pomiędzy tymi punktami często wykazuje dużą regularność (Wallace 1978, Mayer 1986, Hovius 1996, Talling i in. 1997). Bazując na tych zależnościach skonstruowano wskaźnik odstępu (termin dotąd nieobecny w literaturze polskiej, autorska propozycja nazwy za ang. spacing ratio) wyrażający stosunek średniej długości zlewni znajdujących się na zapleczu danego progu (W) do średniej odległości pomiędzy punktami zamykającymi te zlewnie (S) (Wallace 1978). Wyższe wartości wskaźnika powinny odpowiadać zatem frontom górskim o wyższym stopniu aktywności tektonicznej.

Wskaźnik ten stosowano $\mathrm{w}$ badaniach morfotektonicznych w latach 90. XX w. (Hovius 1996, Talling i in. 1997), a liczba prac, w których jest on obecnie wykorzystywany jest niewielka (Delcaillau i in. 2011).

\section{Wskaźniki odnoszące się do geometrii dolin cieków rozcinających fronty górskie}

W większości prac, poświęconych badaniom aktywności tektonicznej krawędziowych stref masywów górskich, analizie wskaźnika krętości towarzyszy analiza wskaźnika szerokości dna - wysokości zboczy doliny (ang. valley floor width - valley height ratio) (Bull 1977, Bull, McFadden 1977), który w polskiej literaturze określany jest niekiedy mianem współczynnika/wskaźnika kształtu doliny (Ranoszek 2001, Brzezińska-Wójcik, Hołub 2007, Brzezińska-Wójcik i in. 2010b, Chabudziński, Brzezińska-Wójcik 2013). Komplementarność tych dwóch wskaźników przy ocenie stopnia aktywności tektonicznej 
frontów górskich została w szczególny sposób podkreślona w pracy Silvy i in. (2003). Wskaźnik szerokości dna - wysokości zboczy doliny wyrażany jest wzorem:

$$
\mathrm{V}_{\mathrm{f}}=2 \mathrm{~V}_{\mathrm{fw}} /\left[\left(\mathrm{E}_{\mathrm{ld}}-\mathrm{E}_{\mathrm{sc}}\right)+\left(\mathrm{E}_{\mathrm{rd}}-\mathrm{E}_{\mathrm{sc}}\right)\right]
$$

gdzie:

$\mathrm{V}_{\text {fw }}$ - szerokość dna doliny [m],

$\mathrm{E}_{\mathrm{ld}}, \mathrm{E}_{\mathrm{rd}}-$ wysokość lewego/prawego wododziału $[\mathrm{m}$ n.p.m.],

$\mathrm{E}_{\mathrm{sc}}-$ wysokość dna doliny [m n.p.m.].

Z matematycznie analogicznego zapisu, w którym mianownik dzielony jest przez licznikową wartość 2 wynika, że wskaźnik ten można zdefiniować jako stosunek szerokości dna doliny do średniej wysokości jej zboczy. Poszczególne wartości ze wzoru odczytywane są w przekroju poprzecznym przez dolinę, zlokalizowanym w pewnej określonej odległości powyżej miejsca, w którym rzeka rozcina próg tektoniczny - jak zauważa Brzezińska-Wójcik (2013), najczęściej nie większej niż 1 km.

Niskie wartości wskaźnika $\mathrm{V}_{\mathrm{f}}$ typowe są dla głęboko wciętych dolin rzecznych rozwijających się w warunkach intensywnego wypiętrzania obszaru, podczas gdy wartości wysokie odpowiadają szerokim dolinom w obszarach o małej aktywności tektonicznej. Ograniczenie lub ustanie tej aktywności sprzyja bowiem poszerzaniu den dolinnych oraz zmniejszaniu wysokości stref wododziałowych (Burbank, Anderson 2011). Przyjmuje się, że wartości wskaźnika z zakresu 0,05-0,50 odpowiadają najwyższej klasie aktywności tektonicznej frontów górskich (Bull 2007).

Zakres wartości wskaźnika uzyskany dla prowincji Basin and Range przez jego twórców wyniósł 0,05-47,0. Należy podkreślić, że przedziały uzyskiwane przez licznych autorów dla obszarów o odmiennych uwarunkowaniach klimatycznych i geologicznych były bardzo zróżnicowane, rzadko jednak rozłączne (np. Cuong, Zuchiewicz 2001a, b, Badura i in. 2003, 2007, Verrios i in. 2004, Al-Taj i in. 2007, Malik, Mohanty 2007, Peters, van Balen, 2007, El Hamdouni i in. 2008, García-Tortosa i in. 2008, Pedrera i in. 2009, Figueroa, Knott 2010, Pérez-Peña i in. 2010, Alipoor i in. 2011, Wiwegwin i in. 2011, Azañón i in. 2012, Brzezińska-Wójcik 2013, Antón i in. 2014).

Niezachodzące na siebie przedziały wartości wskaźnika $\mathrm{V}_{\mathrm{f}}, 0,10-0,33$ oraz 0,59-2,33, uzyskano dla obszarów o odmiennych warunkach klimatycznych odpowiednio w Tajlandii (Singh, Virdi 2007) oraz Iranie (Bafti 2009). Należy jednak podkreślić, że w obu tych przypadkach liczba dokonanych pomiarów była niewielka i wyniosła po pięć. Zakres rozłączny w stosunku do przedziałów pojawiających się w większości wyżej wymienionych pozycji uzyskali Brzezińska-Wójcik i Hołub (2007) w strefie krawędziowej Roztocza Tomaszowskiego oraz Brzezińska-Wójcik i in. (2010a), którzy analizując wartości wskaźnika dla kilkunastu dolin rzecznych w ukraińskiej części Roztocza otrzymali bardzo wysokie jego wartości mieszczące się w przedziale 12,89-28,42.

Rozstęp wskaźnika prezentowany w poszczególnych pracach, rozumiany jako różnica pomiędzy maksymalną a minimalną z zaobserwowanych wartości, był również zróżnicowany i wynosił zarówno poniżej dwóch (García-Tortosa $i$ in. 2008, Pedrera i in. 2009, Pérez-Peña i in. 2010, Azañón i in. 2012), jak i powyżej dziesięciu (Malik, Mohanty 2007, El Hamdouni i in. 2008, Brzezińska-Wójcik i in. 2010a), a niekiedy nawet dwudziestu (Peters, van Balen 2007, Omidali i in. 2015).

$\mathrm{W}$ niektórych pracach wartości wskaźnika $\mathrm{V}_{\mathrm{f}}$ przedstawiano w postaci średniej odnoszącej się do poszczególnych progów tektonicznych bądź ich segmentów (Badura i in. 2003, Silva i in. 2003, Zovoili i in. 2004, Al-Taj i in. 2007, Bull 2007, Peters, van Balen 2007) oraz zlewni rzek rozcinających progi (Kale, Shejwalkar 2008, Mahmood, Gloaguen 2012). I w tym przypadku rozstęp obserwowanych uśrednionych wartości był różny, a dobrym przykładem są wyniki z prac Badury i in. (2003) dla segmentów sudeckiego uskoku brzeżnego z rozstępem uśrednionych wartości równym 1,65 oraz Petersa i van Balena (2007) dla segmentów wschodniego obramowania Rowu Górnego Renu, dla których różnica ta wyniosła 18,00. Niekiedy wartości wskaźnika dla poszczególnych progów wyrażano medianą wartości obliczonych w poszczególnych dolinach (Ranoszek 2001).

$\mathrm{W}$ oparciu o uzyskane wartości wskaźnika $\mathrm{V}_{\mathrm{f}}$ tworzono klasy względnej aktywności tektonicznej frontów górskich i większych obszarów, najczęściej jako element składowy analizy opartej na większej liczbie parametrów morfometrycznych (Silva i in. 2003, Bull 2007, El Hamdouni i in. 2008). Choć wartości graniczne tych klas były zazwyczaj różne, w niektórych opracowaniach opierano je na wielkościach zaproponowanych przez El Hamdouniego i in. (2008) (por. Brzezińska-Wójcik 2013, Chabudziński, Brzezińska-Wójcik 2013, Saberi i in. 2014).

W większości opracowań przekroje poprzeczne, w których obliczano wskaźnik szerokości dna - wysokości zboczy doliny, niezależnie od tego, czy w odniesieniu do danej doliny były to pomiary pojedyncze, czy też kilkukrotne, z których wyciągano później wartość średnią, lokalizowano w odległości nie większej niż $1 \mathrm{~km}$ licząc od strefy uskokowej (np. Cuong, Zuchiewicz 2001a, b, Silva i in. 2003, Singh, Virdi 2007, Zavoili i in. 2004, García-Tortosa i in. 2008, Pedrera i in. 2009, Figueroa, Knott 2010, Pérez-Peña i in. 2010, Altın 2012, Brzezińska-Wójcik 2013, Chabudziński, Brzezińska-Wójcik 2013). W niektórych przypadkach odległość tę ustalano w odgórnie określonym przedziale (np. 0,25-0,5 km lub 0,5-1 km), biorąc jednak pod uwagę wielkość danej zlewni (Tsodoulos i in. 2008, El Hamdouni i in. 2008, Dehbozorgi i in. 2010). Zdarzało się także, że dystans ten przekraczał 1 km (Brzezińska-Wójcik, Hołub 2007, Kale, Shejwalkar 2008, Mahmood, Gloaguen 2012). Dla niektórych obszarów odległość ta wyrażana była jako stały procent całkowitej długości zlewni (Al-Taj i in. 2007), bądź stały procent całkowitej długości doliny (Badura $\mathrm{i}$ in. 2003, 2007). Niekiedy wskaźnik liczono wzdłuż całego biegu rzeki (Zuchiewicz 2010, Antón i in. 2014). Bardzo rzadko stosowanym podejściem było lokalizowanie przekrojów bezpośrednio w strefach uskokowych (Malik, 
Mohanty 2007) - taki dobór miejsc pomiarowych nie jest rekomendowany (Bull 2007). Wreszcie, jak zauważa Ata (2008), wybór odległości, w jakiej były prowadzone pomiary, podyktowany był każdorazowo specyfiką obszaru badań, w tym jego cechami geomorfologicznymi oraz przestrzenną organizacją dolin.

Określając stopień aktywności tektonicznej obszaru na podstawie wartości wskaźnika szerokości dna - wysokości zbocza doliny należy zdawać sobie sprawę z pewnych ograniczeń interpretacyjnych, jakie niesie ze sobą jego stosowanie. Wynikają one z faktu, że cechy geometryczne dolin rzecznych, do których wskaźnik ten się odnosi, nie są zależne tylko i wyłącznie od czynników tektonicznych. Na ich wykształcenie mają wpływ także uwarunkowania litologiczne, przekładające się na odporność podłoża, a także wielkość cieku/zlewni (Bull 2007, Alipoor i in. 2011, Burbank, Anderson 2011). W ten sposób wartości wskaźnika dla dolin rzecznych znajdujących się w tym samym reżimie tektonicznym, np. w jednakowych warunkach tektonicznego dźwigania obszaru, lecz różniących się wielkością przepływu rzek i odpornością podłoża mogą się zasadniczo różnić. W idealnych warunkach wskaźnik ten powinien być więc liczony dla dolin zbliżonego rzędu wielkości wykształconych w skałach o podobnej odporności na czynniki niszczące. W niektórych pracach uzyskane wartości wskaźnika $\mathrm{V}_{\mathrm{f}}$ podawano zatem $z$ oraz bez uwzględniania największych dolin rzecznych (por. np. Cuong, Zuchiewicz 2001a, b).

Przy obliczaniu wskaźnika kształtu doliny istotnym zagadnieniem pozostaje dobór odpowiednich materiałów do wykonywania pomiarów. Zavoili i in. (2004) podkreślają szczególną użyteczność map topograficznych w skali nie mniejszej niż 1:5 000. Brak dostępu do innych materiałów sprawił, że wskaźnik $\mathrm{V}_{\mathrm{f}}$ liczony był na podstawie map w skali 1:50 000 przez Zuchiewicza (2010) oraz przez Brzezińską-Wójcik i in. (2010a), którzy przez wzgląd na ten fakt bardzo ostrożnie podeszli do interpretacji uzyskanych wyników. Silva i in. (2003), dokonujący pomiarów na mapach w skali 1:25 000, zwrócili uwagę na trudność w uzyskaniu wiarygodnych wyników, zwłaszcza przy pomiarach szerokości den dolinnych $\mathrm{V}_{\mathrm{fw}}$, zaznaczając, że w przypadkach, w których było to możliwe, korzystali ze zdjęć lotniczych oraz map w większej skali. Na problem właściwego określania szerokości den dolinnych zwrócił uwagę także Bull (2007), odniósł się on jednak do zbyt niskiej rozdzielczości źródłowych danych cyfrowych. Problem ten zasygnalizowany został także w pracach innych autorów (Pedrera i in. 2009, Pérez-Peña i in. 2010), którzy bazując na cyfrowych modelach wysokościowych o niewystarczającej rozdzielczości, zmuszeniu byli w przypadku wąskich dolin rzecznych do korzystania $\mathrm{z}$ alternatywnych źródeł danych $\mathrm{w}$ postaci zdjęć lotniczych i satelitarnych oraz map topograficznych o większej skali (np. 1:10 000).

Alternatywne podejście do oceny stopnia aktywności tektonicznej frontów górskich na podstawie analizy przekrojów poprzecznych dolin rzecznych przedstawił Mayer (1986), a zaproponowany przez niego wskaźnik ksztaltu przekroju poprzecznego doliny (termin dotąd nieobecny w literaturze polskiej, autorska propozycja nazwy za ang. $V$ ratio), choć wzmiankowany w najnowszych syntezach geomorfologii tektonicznej Bulla (2007) oraz Burbanka i Andersona (2011), nie jest w badaniach częściej wykorzystywany (por. np. Bafti 2009, Samadi 2014, Jami i in. 2013, Khalaj 2015). Parametr ten opisany jest wzorem:

$$
\mathrm{V}=\mathrm{A}_{\mathrm{v}} / \mathrm{A}_{\mathrm{c}}
$$

gdzie:

$A_{v}$ - pole powierzchni przekroju poprzecznego przez doline,

$A_{c}$ - pole powierzchni półkola o promieniu równym wysokości zboczy.

Chociaż w oryginalnej pracy Mayera (1986) wysokość zboczy nie jest precyzyjnie zdefiniowana, a rozpatrywane przypadki uwzględniają jedynie taką samą ich wysokość po obu stronach doliny, to Bull (2007) odnosi się we wzorze do wysokości niższego ze zboczy. Niskie wartości współczynnika odpowiadają głęboko wciętym dolinom rozwijającym się w warunkach aktywnej tektoniki, podczas gdy wartości wysokie opisują szerokie, płaskodenne i płytkie doliny w obszarach o ograniczonej aktywności tektonicznej.

Ponieważ wartość licznika $\mathrm{A}_{\mathrm{v}}$ jest polem przekroju poprzecznego przez dolinę, duży wpływ na wartość wskaźnika ma nachylenie jej zboczy. Zmiany w nachyleniu zachodzą jednak w długim czasie - znacznie dłuższym niż potrzebny jest na dokonanie zmian w odniesieniu do szerokości dna doliny (Bull 2007, Burbank, Anderson 2011). W związku z powyższym, niskie wartości wskaźnika mogą uzyskiwać także V-kształtne doliny w obszarach, w których aktywność tektoniczna co prawda już ustała, lecz procesy denudacyjne nie zdążyły jeszcze w znaczący sposób wpłynąć na zmniejszenie nachylenia zboczy. Zaletą omówionego wcześniej wskaźnika szerokości dna - wysokości zboczy doliny $\left(\mathrm{V}_{\mathrm{f}}\right)$ jest to, że nachylenie zboczy - jako elementów o wysokiej inercji topograficznej sensu Burbank i Anderson (2011) - nie wpływa na jego wartość. Wartość ta w dużym stopniu zależna jest natomiast od szerokości dna doliny $\left(\mathrm{V}_{\mathrm{fw}}\right)$, która pozostaje bardziej czuła na zmienne tendencje tektoniczne w podłożu, szybciej je odzwierciedlając.

\section{Kształt zlewni jako odzwierciedlenie aktywności tektonicznej}

Wśród wskaźników aktywności tektonicznej, które odnoszą się do cech geometrycznych zlewni potoków rozcinających progi tektoniczne, jednym z najczęściej stosowanych jest wskaźnik wydłużenia (ang. basin elongation ratio) zaproponowany po raz pierwszy przez Schumma (1956) i wyrażony wzorem:

$$
\mathrm{R}_{\mathrm{e}}=2(\mathrm{~A} / \pi)^{0,5} / \mathrm{L}
$$


Z powyższego zapisu wynika, że wskaźnik ten można zdefiniować jako stosunek średnicy koła o polu powierzchni równym powierzchni zlewni (A) do maksymalnej długości zlewni (L). Choć maksymalna długość zlewni nie została przez Schumma (1956) jednoznacznie zdefiniowana, a różni autorzy przyjmowali odmienne sposoby jej pomiaru (Cannon 1976), w literaturze często przyjmuje się za Hortonem (1945) oraz Schummem (1954), że jest to odległość wzdłuż linii prostej pomiędzy najbardziej oddalonymi punktami w obrębie zlewni (por. np. Cuong, Zuchiewicz 2001a, b, Badura i in. 2003, 2007, Zuchiewicz 2010, Brzezińska-Wójcik 2013). Wobec tego, wartość wskaźnika $\mathrm{R}_{\mathrm{e}}$ nie powinna nigdy przekroczyć wartości równej 1 . W opracowaniach rzadko jednak podaje się sposób, w jaki dokonywano pomiaru wartości mianownika.

W badaniach morfotektonicznych wskaźnik wydłużenia zlewni na szerszą skalę zaczęto stosować wraz z pojawieniem się pracy Bulla i McFaddena (1977), którzy w oparciu o analizę rozkładu jego wartości uzyskanych dla zlewni w prowincji Basin and Range jako pierwsi zaproponowali klasy aktywności tektonicznej i określające je przedziały, odpowiednio $<0,50 ; 0,50-0,75$ oraz $>0,75$ dla obszarów o silnej, umiarkowanej i ograniczonej aktywności. Generalnie, niższe wartości wskaźnika $\mathrm{R}_{\mathrm{e}}$ odpowiadają bardziej wydłużonym zlewniom rozwijającym się przy wzmożonej aktywności tektonicznej. Ograniczenie tej aktywności stwarza warunki korzystne dla rozwoju zlewni w kierunku bardziej kolistego zarysu (Bull, McFadden 1977, Ramírez-Herrera 1998).

Podział przedstawiony przez autorów amerykańskich przyjmowany był do określania względnej aktywności tektonicznej badanych obszarów przez licznych autorów, zwłaszcza polskich, choć nie tylko (Cuong, Zuchiewicz 2001a, b, Forma, Zuchiewicz 2002, Brzezińska-Wójcik 2002, 2013, Brzezińska-Wójcik i in. 2002, Badura i in. 2003, 2007, 2008, Pánek 2004, Brzezińska-Wójcik, Hotub 2007, Brzezińska-Wójcik i in. 2010a, b, Altın 2012, Chabudziński, Brzezińska-Wójcik 2013). Zakres wartości wskaźnika przedstawiany w poszczególnych pracach był różny (por. dodatkowo Ranoszek 2001, Shtober-Zisu i in. 2008), bardzo rzadko jednak obserwowane wartości maksymalne osiągały graniczną wartość wskaźnika równą 1 (por. Brzezińska-Wójcik i in. 2010a, Brzezińska-Wójcik 2013).

W pracach zagranicznych kształt zlewni, który miał wskazywać na tendencje tektoniczne w podłożu, określano znacznie częściej w oparciu o wskaźnik ksztaltu zlewni (ang. drainage basin shape ratio) (np. Jamieson i in. 2004, El Hamdouni i in. 2008, Gürbüz, Gürer 2008, Shtober-Zisu i in. 2008, Tsodoulos i in. 2008). Wskaźnik ten wyraża się wzorem:

$$
\mathrm{B}_{\mathrm{s}}=\mathrm{B}_{\mathrm{l}} / \mathrm{B}_{\mathrm{w}}
$$

gdzie:

$\mathrm{B}_{1}$ - maksymalna długości zlewni,

$\mathrm{B}_{\mathrm{w}}$ - maksymalna szerokość zlewni.

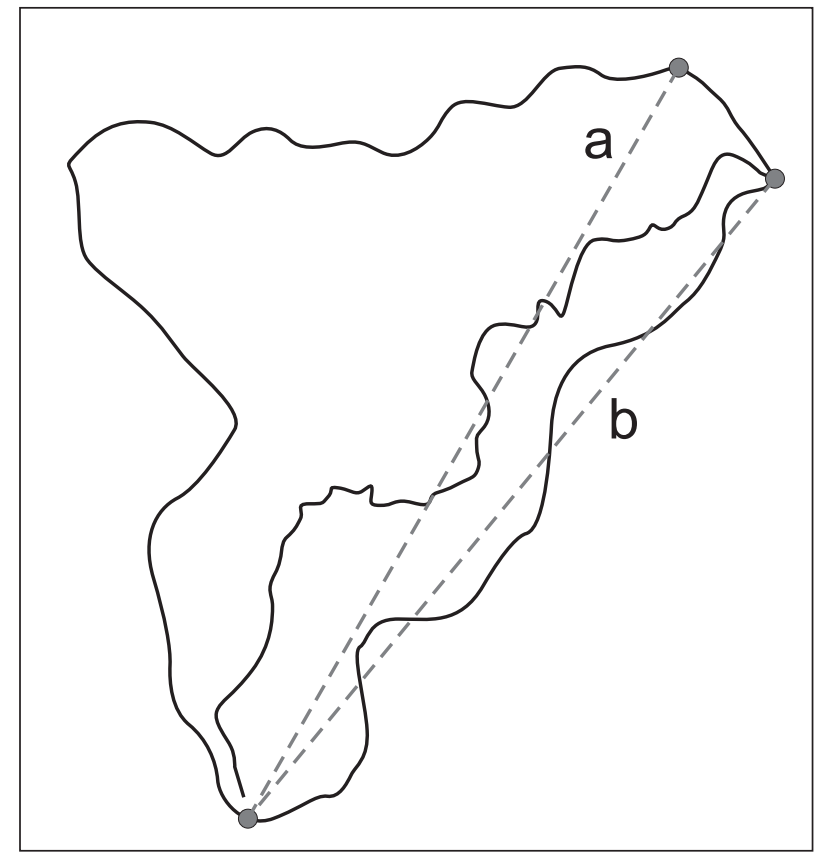

Ryc. 2. Maksymalna długość zlewni

a - odległość pomiędzy dwoma najbardziej od siebie oddalonymi punktami na jej obwodzie, b - odległość od punktu zamykającego zlewnię do punktu najdalej położonego na dziale wodnym (Cannon 1976, zmienione)

Fig. 2. Maximum length of drainage basin

$\mathrm{a}$ - the distance between two points on its perimeter most spaced apart, $b$ - the distance between its outlet and the most distant point on the drainage divide (Cannon 1976, modified)

Choć wielu autorów powołuje się na Cannona (1976) jako twórcę wskaźnika, w rzeczywistości do literatury wprowadziła go Ramírez-Herrera (1998). Do wcześniejszej publikacji autorka odniosła się jedynie przez wzgląd na fakt, że autor uściślił w niej to, co rozumieć należy pod pojęciem maksymalnej długości zlewni. Wskazał on na linię prostą pomiędzy dwoma najbardziej od siebie oddalonymi punktami na jej obwodzie - de facto jako jedną z trzech możliwości, którą Ramírez-Herrera (1998) zdecydowała się przyjąć do obliczania wartości własnego wskaźnika. Co ciekawe, sama autorka powołując się na tę pracę, przyjęła nie do końca jednak tożsame rozwiązanie, zdefiniowała bowiem licznikową wartość $\mathrm{B}_{1}$ jako odległość od punktu zamykającego zlewnię do punktu najdalej położonego na dziale wodnym - jak wynika z ryc. 2, odległości te nie muszą sobie odpowiadać. Niezależnie od tych nieścisłości interpretacja wskaźnika opiera się na założeniu, że wyższe jego wartości odpowiadają bardziej wydłużonym zlewniom, wskazując jednocześnie na relatywnie wyższą aktywność tektoniczną obszaru (Ramírez-Herrera 1998).

Uzyskiwane przez poszczególnych autorów wartości wskaźnika $\mathrm{B}_{\mathrm{s}}$ mieściły się w przedziale od 0,79 (Sahebari i in. 2015) do 8,38 (Tsodoulos $i$ in. 2008). W oparciu o rozkład tych wartości tworzono klasy względnej aktywności tektonicznej o różnych wartościach granicznych (Jamieson i in. 2004, El Hamdouni i in. 2008, Mahmood, Gloaguen 2012), niekiedy przyjmując bezpośrednio po- 
dział zaproponowany przez El Hamdouniego i in. (2008) (Dehbozorgi i in. 2010, Sahebari i in. 2015).

Liczba polskich opracowań morfotektonicznych, w których w analizowanym okresie wskaźnik ten uwzględniano jest bardzo niewielka (Brzezińska-Wójcik 2013, Chabudziński, Brzezińska-Wójcik 2013). Jest on w nich określany mianem planimetrycznego wskaźnika kształtu zlewni w odróżnieniu od wzmiankowanych wskaźników kształtu zlewni zaproponowanych przez Hortona (1932) oraz Singha (1988). Taka jego nazwa bywa $\mathrm{z}$ rzadka przyjmowana w pracach obcojęzycznych (Shtober-Zisu i in. 2008), w których zdarza się także, że wskaźnik ten określany jest mianem wskaźnika wydłużenia (elongation ratio) (Jamieson i in. 2004).

Zakres wartości planimetrycznego wskaźnika kształtu zlewni uzyskany przez Brzezińską-Wójcik (2013) w odniesieniu do annopolsko-lwowskiego segmentu pasa wyżynnego jest znaczny i wynosi 0,68-8,75. Statystyczna analiza rozkładu tych wartości pozwoliła na wydzielenie 3 klas względnej aktywności tektonicznej obszaru określonych wartościami $>2,65$ (wysoka), 2,65-1,30 (umiarkowana) oraz $<1,30$ (niska).

W niektórych opracowaniach, powołując się na specyfikę obszaru badań, wskaźnik ten zmodyfikowano, dzieląc maksymalną długość zlewni $B_{1}$ przez średnią jej szerokość $\mathrm{B}_{\mathrm{mw}}$, którą obliczono dla dziesięciu odcinków biegnących prostopadle do linii wyznaczającej maksymalną długość zlewni (Bahrami 2013).

Znacznie rzadziej w badaniach nad współczesną mobilnością tektoniczną obszarów wykorzystywano wymienione już wcześniej wskaźniki kształtu zlewni zaproponowane przez Hortona (1932) oraz Singha (1988), a także wskaźnik lemniskaty (Chorley 1957).

Horton (1932) przy obliczaniu wskaźnika ksztaltu zlewni (ang. form factor) odniósł powierzchnię zlewni (A) do pola kwadratu o boku równym maksymalnej długości zlewni (L) zgodnie ze wzorem:

$$
\mathrm{Rf}=\mathrm{A} / \mathrm{L}^{2}
$$

Maksymalna długość zlewni nie została przez autora jednoznacznie zdefiniowana. Przyjmując, że jest to odległość pomiędzy najbardziej od siebie oddalonymi punktami na jej obwodzie, wskaźnik ten nie powinien odwrotnie niż wskazuje Zăvoianu (1985) - przekroczyć granicznej wartości $\pi / 4(\approx 0,785)$, jaka charakteryzowałaby zlewnię o idealnie kolistym kształcie. Zakładając, że maksymalna długość zlewni jest odległością od punktu zamykającego zlewnię do punktu najdalej położonego na dziale wodnym sensu Ramírez-Herrera (1998), wskaźnik ten może uzyskiwać wyższe wartości, przekraczające także 1, w przypadku, w którym długość ta jest mniejsza od szerokości zlewni. Generalnie jednak, im bardziej wydłużona jest zlewnia, tym niższe wartości wskaźnik ten przyjmuje.

Wskaźnik Rf obliczany był dla zlewni potoków rozcinających próg tektoniczny związany z przebiegiem sudeckiego uskoku brzeżnego na odcinku od Dobromierza po Złoty Stok (Badura i in. 2003) oraz od Złotoryi po Jesenik (Badura i in. 2007), gdzie przyjmował wartości z przedziałów odpowiednio $0,15-0,56$ oraz $0,15-0,63$. W strefie krawędziowej ukraińskiej części Roztocza oraz dla całego annopolsko-lwowskiego segmentu pasa wyżynnego zakresy uzyskanych wartości były większe i wyniosły odpowiednio 0,05-1,00 (Brzezińska-Wójcik i in. 2010a) oraz 0,09-0,99 (Brzezińska-Wójcik 2013). W obu tych przypadkach wyróżniono trzy klasy względnej aktywności tektonicznej o wartościach Rf poniżej 0,25 , od 0,25 do 0,50 oraz powyżej 0,50 . Klasyfikację taką przyjęto również $\mathrm{w}$ pracy dotyczącej oceny przejawów neotektoniki w zlewni górnego Wieprza (Chabudziński, Brzezińska-Wójcik 2013).

W badaniach prowadzonych przez autorów zagranicznych omawiany wskaźnik wykorzystywany był w czysto hydrograficznej charakterystyce, z ograniczoną liczbą prac, w których wyniki odnoszono bezpośrednio do sytuacji tektonicznej (Kouli i in. 2006, Shukla i in. 2014).

Jak zauważa Brzezińska-Wójcik (2013), także wskaźnik kształtu zlewni Singha (1988), stanowiący odwrotność wskaźnika Rf, oraz wskaźnik lemniskaty k (Chorley 1957, por. Tabela 1, gdzie: L - maksymalna długość zlewni, A - powierzchnia zlewni) stosowano głównie w hydrograficznych opisach zlewni, a niekiedy tylko jako pomocnicze w badaniach morfotektonicznych. Z uwagi na ten fakt, nie będą tu szerzej omawiane. Do określania względnej aktywności tektonicznej obszaru były one łącznie wykorzystywane w pracach Chabudzińskiego i Brzezińskiej-Wójcik (2013) oraz Brzezińskiej-Wójcik (2013). Wskaźnik k posłużył tym celom dodatkowo w pracach Badury i in. (2003) oraz Brzezińskiej-Wójcik $\mathrm{i}$ in. (2010a). Wśród autorów zagranicznych natomiast zastosowali go Lykoudi i Angelaki (2004).

W oparciu o powierzchnię i obwód zlewni jej kształt starał się ilościowo określić Miller (1953) - twórca wskaźnika kolistości zlewni (ang. circularity ratio) który odniósł jej powierzchnię (A) do powierzchni koła o obwodzie równym obwodowi zlewni (P). Wskaźnik ten opisany jest wzorem:

$$
\mathrm{RC}=4 \pi \mathrm{A} / \mathrm{P}^{2}
$$

Z takiego zapisu wynika, że wskaźnik RC osiąga wartość równą jedności dla zlewni o idealnie kolistym zarysie, maleje do $\pi / 4(\approx 0,785)$ dla zlewni w kształcie kwadratu i osiąga coraz to niższe wartości przy wzroście jej wydłużenia.

W badaniach prowadzonych przez autorów polskich uzyskano zbliżone zakresy wartości omawianego wskaźnika dla różnych obszarów: 0,32-0,90 dla zlewni potoków rozcinających próg biegnący wzdłuż sudeckiego uskoku brzeżnego (Badura i in. 2003, 2007), 0,20-0,89 dla ukraińskiej części Roztocza (Brzezińska-Wójcik i in. 2010a) oraz 0,23-0,89 dla całego annopolsko-lwowskiego segmentu pasa wyżynnego (Brzezińska-Wójcik 2013). Wskaźnik ten, jako jeden z kilku, przyjęto ponadto do oceny stopnia aktywności tektonicznej w zlewni górne- 
go Wieprza, z podziałem na trzy klasy aktywności tektonicznej wraz $\mathrm{z}$ odpowiadającymi im wartościami $<0,50$, 0,50-0,75 oraz >0,75 (Chabudziński, Brzezińska-Wójcik 2013).

Wśród prac zagranicznych szczególną uwagę zwracają bardzo niskie, bo bliskie zeru $(0,04-0,11)$ wartości wskaźnika uzyskane dla czterech zlewni w Dolinie Kaszmiru (Dar i in. 2014), a także przekraczająca 1 wartość wskaźnika dla zlewni Vidarbha (Khadri, Kharbadkar 2013), będące efektem błędnych obliczeń. Teoretyczny przedział wartości wskaźnika kolistości zlewni, jak podkreślają Forestier i in. (2008), określony jest bowiem przez ekstrema 0 dla linii oraz 1 dla koła.

Nie częściej wykorzystywano w badaniach wskaźnik zwartości zlewni (ang. drainage basin compactness) (Engstrom 1989), który stanowi stosunek obwodu zlewni (P) do jej powierzchni (A):

$$
\mathrm{B}_{\mathrm{c}}=\mathrm{P} / \mathrm{A} \text {. }
$$

Przy interpretacji tego wskaźnika przyjęto, że wyższe jego wartości odpowiadają zlewniom rozwijającym się przy długotrwałym udziale erozji przebiegającej w warunkach względnego spokoju tektonicznego. Poszczególni autorzy uzyskiwali różne rzędy wielkości tego wskaźnika (por. np. Pánek 2004, Altın 2012, Brzezińska-Wójcik 2013, Chabudziński, Brzezińska-Wójcik 2013), a problem ich porównywalności wynika z faktu, że przyjmowane były niejednakowe jednostki dla pomiaru obwodu i powierzchni zlewni.

Znaczne ograniczenia w interpretacji tej prostej miary wynikają z faktu, że nie uwzględnia ona w żaden sposób cech litologicznych podłoża, decydujących o jego odporności na niszczenie. W związku z powyższym, wartości wskaźnika $\mathrm{B}$ nie muszą odzwierciedlać wcale tendencji tektonicznych, lecz jedynie zróżnicowanie litologiczne, przy czym wyższe wartości będą wówczas typowe dla zlewni wykształconych w skałach o niższej odporności. Aspekt ten porusza w swoim opracowaniu Brzezińska-Wójcik (2013).

\section{Asymetria zlewni jako wskaźnik aktywności tektonicznej}

Zlewnie na obszarach aktywnych tektonicznie cechują się często asymetrią, którą należy rozumieć jako powierzchniową przewagę jednej ich części, prawej bądź lewej, nad drugą. Sytuacje takie odzwierciedla ilościowo wskaźnik asymetrii zlewni (ang. asymmetry factor) (Hare, Gardner 1985), wyrażony wzorem:

$$
\mathrm{AF}=100\left(\mathrm{~A}_{\mathrm{r}} / \mathrm{A}\right)
$$

gdzie:

$\mathrm{A}_{\mathrm{r}}$ - powierzchnia prawej części zlewni,

A-całkowita powierzchnia zlewni.

Zlewnie symetryczne przyjmują wartości wskaźnika bliskie 50. Powierzchniowa przewaga prawej części zlewni wyrażana jest wartościami większymi niż 50, lewej natomiast - mniejszymi. Wskaźnik ten jest czuły na tektoniczne przechylanie obszaru prostopadłe do przebiegu głównego cieku w zlewni.

Wskaźnik ten obliczono dla zlewni potoków w strefie sudeckiego uskoku brzeżnego (Badura i in. 2003, 2007), gdzie przyjął on zróżnicowane wartości z zakresu 15,480,8 . Jeszcze większy rozstęp wartości wskaźnika uzyskała Brzezińska-Wójcik (2013) w odniesieniu do zlewni w annopolsko-lwowskim segmencie pasa wyżynnego (0,09-99,98). Odmiennie, zbliżone do siebie i oscylujące wokół 50 wartości wskaźnika AF uzyskali dla zlewni potoków rozcinających podnóże skarpy Dam Tao w Wietnamie Cuong i Zuchiewicz (2001a, b). Wskaźnik ten dla zlewni na zapleczach progów tektonicznych w Sudetach zastosował również Ranoszek (2001), przyjmując do dalszej interpretacji wartości centralne tego wskaźnika, obliczonego w zmodyfikowanej wersji zgodnej z równaniem:

$$
A F=50-\left(A_{r} / A \times 100\right)
$$

W tym przypadku wartości dodatnie miały odpowiadać powierzchniowej przewadze lewej części zlewni, ujemne natomiast prawej. W ten sam sposób wskaźnik ten liczyli również Pérez-Peña i in. (2010) oraz Mahmood i Gloaguen (2012), z tą jednak różnicą, że jego wartości przedstawiono w postaci bezwzględnej:

$$
\mathrm{AF}=\left|50-\left(\mathrm{A}_{\mathrm{r}} / \mathrm{A} \times 100\right)\right|
$$

Przyjmowanie przez wskaźnik jedynie nieujemnych wartości oznaczało utratę informacji o kierunku asymetrii, ułatwiło jednak sposób zapisu przedziałów jego wartości dla klas aktywności tektonicznej - pozwoliło bowiem na wyeliminowanie dwóch przedziałów rozłącznych przypisanych tej samej klasie (por. np. Dehbozorgi i in. 2010, Brzezińska-Wójcik 2013). Zbliżony sposób zapisu przy określaniu wartości granicznych odpowiadających trzem klasom aktywności tektonicznej przyjęli wcześniej El Hamdouni i in. (2008). Na utratę informacji o kierunku asymetrii zlewni poprzez zastosowanie procentowego wskaźnika asymetrii zlewni wyrażonego poniższym wzorem zdecydował się również Bahrami (2013):

$$
\mathrm{PAF}=(\mathrm{ALS} / \mathrm{A}) \times 100
$$

gdzie:

ALS - powierzchnia większej części zlewni,

A- całkowita powierzchnia zlewni.

Wskaźnik asymetrii zlewni jest bardzo często uwzględniany jako składowy przy badaniu względnej aktywności tektonicznej obszarów w oparciu o większą liczbę parametrów morfometrycznych (np. Tsodoulos $\mathrm{i}$ in. 2008, Alipoor i in. 2011, Azañón i in. 2012), jego zastosowanie nie pozostaje jednak wolne od pewnych ograniczeń interpretacyjnych. Są one związane z faktem, że asymetria zlewni nie musi wynikać jedynie z aktywności 
tektonicznej obszaru, lecz może mieć także uwarunkowania litologiczne lub strukturalne. Zwracają na to uwagę Salvany (2004), El Hamdouni i in. (2008), a także Brzezińska-Wójcik (2013).

Alternatywne podejście ilościowe do określania asymetrii zlewni zaproponował Cox (1994) - twórca wskaźnika poprzecznej asymetrii topograficznej (tłum. za Cuong, Zuchiewicz 2001a) (ang. transverse topographic symmetry factor) wyrażanego wzorem:

$$
\mathrm{T}=\mathrm{Da} / \mathrm{Dt}
$$

gdzie:

Da - odległość od osi zlewni do osi koryta rzecznego,

Dt - odległość od osi zlewni do działu wodnego, liczona w tym samym co Da kierunku.

Wartości tego wskaźnika zmieniają się w przedziale od 0 do 1, odpowiednio dla zlewni symetrycznych oraz cechujących się skrajną asymetrią. Wskaźnik ten nie byłza wyjątkiem nielicznych opracowań (Cuong, Zuchiewicz 2001a, b) - wykorzystywany w badaniach morfotektonicznych prowadzonych przez polskich autorów. Stosunkowo często natomiast stosowali go autorzy zagraniczni, zarówno w połączeniu ze wskaźnikiem asymetrii zlewni AF (np. Tsodoulos i in. 2008, Alipoor i in. 2011), jak też alternatywnie do niego (np. Toudeshki, Arian 2011, Altın 2012). Wartość wskaźnika określająca stopień asymetrii danej zlewni była najczęściej średnią arytmetyczną z kilku pomiarów prowadzonych wzdłuż całej jej długości, choć zdarzało się także, że nie w pełni reprezentatywnie odczytywana ona była w jednym tylko miejscu (Ramesht i in. 2011).

\section{Wskaźniki wysokościowe charakteryzujące zlewnie}

Określania stopnia aktywności tektonicznej obszaru podejmowano się także w oparciu o analizę cech wysokościowych zlewni. Jak zauważa Pánek (2004), najprostszą miarą, która pozwala na pierwsze, przybliżone spojrzenie na intensywność ruchów tektonicznych jest maksymalna deniwelacja, a więc różnica pomiędzy maksymalną a minimalną wysokością na danym obszarze. Miara ta, bardzo rzadko analizowana w odosobnieniu (por. np. Badura i in. 2003, Brzezińska-Wójcik 2013), częściej obliczana jest na potrzeby zastosowania innych wskaźników wysokościowych, takich jak całka hipsometryczna (Strahler 1952), wskaźnik rzeźby (Schumm 1956) oraz wskaźnik wysokości względnych (Melton 1957, 1958).

Wskaźnikiem często wykorzystywanym przez autorów zagranicznych jest całka hipsometryczna (ang. hypsometric integral) (Strahler 1952), wyrażana w pracach wzorem:

$$
\mathrm{Hi}=\left(\mathrm{H}_{\text {mean }}-\mathrm{H}_{\text {min }}\right) /\left(\mathrm{H}_{\text {max }}-\mathrm{H}_{\text {min }}\right)
$$

gdzie:
$\mathrm{H}_{\min }, \mathrm{H}_{\max }-$ minimalna i maksymalna wysokość w zlewni [m n.p.m.],

$\mathrm{H}_{\text {mean }}$ - średnia arytmetyczna wysokość [m n.p.m.].

W rzeczywistości autorzy nie posługują się ściśle całką hipsometryczną sensu Strahler (1952), lecz pewnym jej uproszczeniem, zaaplikowanym przez wzgląd na skomplikowany sposób obliczania jej wartości (Wieczorek, Żyszkowska 2011). W polskiej literaturze ten rzadko stosowany wskaźnik bywa nazywany wskaźnikiem zróżnicowania wysokości (Brzezińska-Wójcik 2013, Chabudziński, Brzezińska-Wójcik 2013).

Wartości wskaźnika Hi mieszczą się w przedziale od 0 do 1 . Przyjmuje się, że wysokie wartości $(>0,60)$ odpowiadają obszarom aktywnym tektonicznie (Pánek 2004). Wartość 0,60 została uznana za dolną odpowiadającą młodemu etapowi rozwoju rzeźby tektonicznej, w którym utrata masy wskutek procesów erozyjnych jest jeszcze niewielka (Strahler 1952). Ten młody etap rozwoju krajobrazu może być, jak podkreślają El Hamdouni i in. (2008) oraz Mahmood i Gloaguen (2012), wynikiem ożywienia aktywności tektonicznej.

Wartości wskaźnika prezentowane są najczęściej w połączeniu z krzywymi hipsograficznymi (np. Pedrera i in. 2009, Pérez-Peña i in. 2010, Dehbozorgi i in. 2010, Alipoor i in. 2011, Delcaillau i in. 2011, Azañón i in. 2012), które przedstawiają graficznie rozkład wysokości w zlewni. Wartość wskaźnika Hi odpowiada polu powierzchni pod krzywą hipsograficzną. Krzywa ta przedstawiana jest najczęściej w prostokątnym układzie współrzędnych, którego obie osie - pionowa zrelatywizowanej wysokości i pozioma zrelatywizowanej powierzchni ograniczone są wartościami 0 i 1. Wypukły kształt krzywej, tj. duży procent powierzchni zlewni przypadający na obszary o relatywnie dużych wysokościach, łączony jest z młodszym etapem rozwoju rzeźby sensu Strahler (1952) i większą aktywnością tektoniczną obszaru (Chen i in. 2003, Pánek 2004).

W Polsce wskaźnik Hi obliczany był dla zlewni w annopolsko-lwowskim segmencie pasa wyżynnego, gdzie większość badanych jednostek $(64,8 \%)$ uznano za średnio aktywne tektonicznie, tj. przyjmujące wartości wskaźnika z przedziału 0,45-0,65 (Brzezińska-Wójcik 2013). W Karpatach stopień dojrzałości rzeźby, uwarunkowany w pewnej mierze aktywnością tektoniczną, badał m.in. Zuchiewicz (2010), posiłkując się dodatkowo tzw. wskaźnikiem rozwoju (Rd), który miał identyfikować obszary charakteryzujące się silnym odmładzaniem rzeźby $(\mathrm{Rd}<100 \%)$. Wskaźnik ten zdefiniowano jako wyrażony procentowo stosunek powierzchni zawartej pomiędzy teoretyczną krzywą stadium młodocianego Strahlera (1952) a krzywą dla danej zlewni do powierzchni zawartej pomiędzy krzywą dla danej zlewni a teoretyczną krzywą stadium starczego.

Ograniczenia interpretacyjne związane z wykorzystywaniem wskaźnika Hi wynikają z faktu, że na stosunki wysokościowe w zlewniach mają wpływ nie tylko czynniki tektoniczne, ale także klimatyczne i litologiczne. Krótkiego przeglądu prac, w których rozpatrywano 
wpływ czynników pozatektonicznych na kształt krzywych hipsograficznych dokonują Chen i in. (2003). W literaturze nie ma zgodności co do wpływu rozmiaru zlewni na wielkość omawianego wskaźnika (Brzezińska-Wójcik 2013).

Wskaźnik rzeźby (ang. relief ratio) (Schumm 1956) definiowany jest jako stosunek maksymalnej deniwelacji (H) do długości zlewni (L):

$$
\mathrm{Rh}=\mathrm{H} / \mathrm{L} \text {. }
$$

Przyjmuje się, że niskie jego wartości wskazują na tektoniczne wypiętrzanie obszaru (Badura i in. 2003, 2007, Brzezińska-Wójcik 2013). Wartości tego wskaźnika będą tym niższe, im większe będzie wydłużenie zlewni (L) oraz im mniejsze będą maksymalne deniwelacje (H). Problem wynika natomiast z faktu, że wzrost maksymalnej deniwelacji $(\mathrm{H})$, wpływający na wzrost wartości wskaźnika Rh, tj. w świetle powyższej interpretacji na osłabienie aktywności tektonicznej, jest w literaturze powszechnie uznawany za wskaźnik odmłodzenia rzeźby, które następuje właśnie na skutek młodych ruchów wypiętrzających (Badura i in. 2003, 2007, Brzezińska-Wójcik 2013). Przyjmując zatem, że obszary aktywnie dźwigane tektonicznie cechują się większymi deniwelacjami, to niższe wartości wskaźnika nie powinny w takim przypadku świadczyć o wzmożonej aktywności tektonicznej.

Wskaźnik ten wykorzystywany był najczęściej w hydrograficznej charakterystyce zlewni, znacznie rzadziej natomiast jako pomocniczy w badaniach morfotektonicznych, zwłaszcza przez autorów zagranicznych (Jamieson i in. 2004, Pánek 2004, Shukla i in. 2014). Niektórzy wskaźnik ten obliczali jako stosunek maksymalnej deniwelacji zlewni do długości głównego cieku wodnego (Figueroa, Knott 2010).

Niewielka jest także liczba prac, w których wskaźnik ten uwzględniali polscy autorzy (Badura i in. 2003, 2007, Brzezińska-Wójcik i in. 2010a, Brzezińska-Wójcik, 2013, Chabudziński, Brzezińska-Wójcik 2013). W tych samych opracowaniach wykorzystano pomocniczo wskaźnik wysokości względnych Rhp (ang. relative relief) (Melton 1957, 1958) - odnoszący maksymalną deniwelację zlewni $(\mathrm{H})$ do jej obwodu $(\mathrm{P})$ - który także nie należy do często wykorzystywanych w badaniach morfotektonicznych.

\section{Wskaźniki odnoszące się do cech systemu rzecznego}

Parametry opisujące cechy systemu rzecznego w zlewni (wskaźnik bifurkacji, wskaźnik gęstości sieci drenażu, wskaźnik liczby cieków, wskaźnik $\mathrm{N}_{1} / \mathrm{N}$ ), liczone najczęściej zgodnie z klasyfikacją sieci rzecznej Hortona-Strahlera (por. np. Matsuda 2004, Zuchiewicz 2010), znalazły zastosowanie w badaniach nad młodą aktywnością tektoniczną obszarów, choć znacznie częściej wykorzystywano je w hydrograficznej charakterystyce zlewni.
W badaniach morfotektonicznych prowadzonych przez autorów polskich wskaźniki te nie były w analizowanym przedziale czasu wykorzystywane, stąd poniższy przegląd uwzględniał będzie prace zagraniczne. Wspomnieć jednak należy, że we wcześniejszym okresie przy ich zastosowaniu określano mobilność neotektoniczną głównie Karpat, a krótkiego przeglądu uzyskanych wyników dokonał Zuchiewicz (2010).

Wskaźnik bifurkacji (ang. bifurcation ratio) (Horton 1932) odnosi liczbę cieków danego rzędu w zlewni do liczby cieków wyższego rzędu zgodnie ze wzorem:

$$
\mathrm{R}_{\mathrm{b}}=\mathrm{N}_{\mathrm{u}} / \mathrm{N}_{\mathrm{u}+1}
$$

gdzie:

$\mathrm{N}$ - liczba cieków,

$\mathrm{u}$ - rząd cieku.

Dla całej zlewni liczony jest jako średnia arytmetyczna $n$ takich stosunków (Pánek 2004, Bahrami 2013, Shukla $i$ in. 2014), a jest ona tym wyższa, im wyższy stopień rozwinięcia (,rozgałęzienia”) sieci rzecznej. Wysoki stopień erozyjnego rozcięcia może cechować obszary wykazujące wysokie tempo podnoszenia tektonicznego ( $\mathrm{Zu}-$ chiewicz 2010), aczkolwiek wypływ innych czynników, w tym głównie struktury podłoża, musi być wzięty pod uwagę. Przykładowo, wysokie wartości będą typowe dla obszarów występowania skał bardzo podatnych na erozję liniową, tzw. badlandów.

W niektórych opracowaniach (Guarnieri, Pirrotta 2008, Raj 2012) badania wpływu tektoniki na cechy systemu rzecznego opierano na tzw. bezpośrednim wskaźniku bifurkacji $\mathrm{R}_{\mathrm{db}}$ (ang. direct bifurcation index) oraz indeksie bifurkacji R (ang. bifurcation index), wprowadzonych dla lepszego zobrazowania cech systemu rzecznego (Avena $\mathrm{i}$ in. 1967).

W ciekawy sposób wskaźnik bifurkacji zaaplikowali Zuchiewicz i McCalpin (2000). Wskaźnik ten, pierwotnie obliczany dla sieci rzecznej, wykorzystali oni bowiem do charakterystyki lic trójkątnych rozwiniętych na progu związanym z przebiegiem uskoku Wasatch w prowincji Basin and Range. Klasyfikację Hortona-Strahlera zastosowali w odniesieniu do linii wododziałowych rozwiniętych w obrębie złożonych systemów lic kilku generacji. Wyższe wartości wskaźnika $\mathrm{R}_{\mathrm{b}}$ osiągane przez lica w jednym $z$ czterech badanych segmentów progu miały wskazywać na wyższy stopień rozcięcia erozyjnego i degradację postępującą w warunkach mniejszej aktywności tektonicznej.

Stopień erozyjnego rozcięcia obszaru określają ponadto wskaźniki gęstości sieci drenażu oraz wskaźnik liczby cieków. Wskaźnik gęstości sieci drenażu (Neumann 1900, za Horton 1932) (ang. drainage density) wyraża stosunek całkowitej długości cieków na danym obszarze do jego powierzchni $\left(\mathrm{D}_{\mathrm{d}}=\Sigma \mathrm{L} / \mathrm{A}\right)$, natomiast wskaźnik liczby cieków - odpowiednik wskaźnika częstości sieci dolinnej sensu Zuchiewicz (2010) - (ang. stream density, za Horton 1932, częściej natomiast stream frequency w literaturze zagranicznej) stosunek liczby cieków okre- 
ślonego rzędu do powierzchni zlewni $\left(\mathrm{F}=\mathrm{N}_{\mathrm{u}} / \mathrm{A}\right)$. Wysoki stosunek liczby cieków pierwszego rzędu do całkowitej liczby cieków na danym obszarze $\left(\mathbf{N}_{1} / \mathbf{N}\right)$ uznawany jest za wskaźnik intensywnego odmładzania rzeźby związanego z wypiętrzaniem obszaru (Zuchiewicz 1980, 1989, 2010).

Miary te nie są zbyt często wykorzystywane w badaniach z zakresu geomorfologii tektonicznej, jako że rozwój sieci rzecznej zależny jest od bardzo dużej liczby czynników. Jak zauważają Simoni i in. (2003) oraz Shukla i in. (2014), spośród nich największe znaczenie przypisuje się uwarunkowaniom litologiczno-strukturalnym, przekładającym się na wielkość infiltracji, a także klimatycznym. W kontekście aktywności tektonicznej powyższe wskaźniki są również odmiennie interpretowane. Dla przykładu, obszarom o niskich wartościach wskaźnika $\mathrm{D}_{\mathrm{d}}$ przypisuje się zarówno większą (Pánek 2004, Keller, Pinter 2002, za Melosh, Keller 2013), jaki i mniejszą (Simoni i in. 2003) aktywność tektoniczną. W niewielu też pracach, w których wskaźniki te obliczano, wyniki odnoszono wprost do aktywności tektonicznej obszaru.

\section{Wskaźniki odnoszące się do spadku cieków}

Analiza profili podłużnych rzek, jako tych elementów systemu geomorfologicznego, które najszybciej reagują na niewielkie nawet zmiany w nachyleniu powierzchni wywołane ruchami tektonicznymi (Burbank, Anderson 2011), znalazła szerokie zastosowanie w badaniach neotektonicznych. Analizie tej towarzyszy często obliczanie wskaźnika długości-spadku rzeki (ang. stream length gradient index) (Hack 1973) wyrażanego wzorem:

$$
\mathrm{SL}=(\Delta \mathrm{H} / \Delta \mathrm{L}) \mathrm{L}
$$

gdzie:

$\Delta \mathrm{H} / \Delta \mathrm{L}$ - spadek badanego odcinka cieku: $\Delta \mathrm{H}$ - różnica wysokości pomiędzy punktem początkowym, a punktem końcowym odcinka; $\Delta \mathrm{L}$ - horyzontalna długość odcinka,

L - horyzontalna odległość od źródeł rzeki do punktu wyznaczającego środek odcinka, dla którego liczony jest wskaźnik.

Jak zauważają Burbank i Anderson (2011), powyższy wzór należy stosować dla relatywnie krótkich odcinków cieku, dla których założenie stałego spadku jest możliwe. W literaturze przyjmuje się bądź stałą długość badanych odcinków (np. Štěpančíková i in. 2008, Troiani, Della Seta 2008, Pedrera i in. 2009, Pérez-Peña i in. 2009), bądź jednakowy interwał określających je wysokości $(\Delta \mathrm{H})(\mathrm{np}$. Ranoszek 2001, Peters, van Balen 2007, García-Tortosa i in. 2008, Tsodoulos i in. 2008). Najczęściej jednak opis przyjętej metodyki informacji takiej nie uwzględnia.

W różny sposób definiowana jest również wartość L: jako długość całego cieku (Forma, Zuchiewicz 2002, Zuchiewicz 2010, Toudeshki, Arian 2011), odległość od źródeł do punktu wyznaczającego środek badanego odcinka (Guarnieri, Pirrotta 2008, Wiwegwin i in. 2011,
Azañón i in. 2012, Raj 2012) lub odległość od wododziału do punktu wyznaczającego ten środek (El Hamdouni $\mathrm{i}$ in. 2008, Alipoor i in. 2011, Burbank, Anderson 2011, Antón i in. 2014). W niektórych opracowaniach długość ta nie jest jednoznacznie precyzowana (Zavoili i in. 2004, Ramesht $i$ in. 2011).

Wskaźnik SL jest wrażliwy na zmiany spadku rzeki, a wyższe jego wartości mogą wynikać zarówno z wpływu czynnika tektonicznego (wypiętrzanie), jak i litologicznego, tj. większej odporności skał na erozję. Ponieważ jego interpretacja nie może być prowadzona bez rozpatrywania wpływu obu tych czynników na uzyskane wartości, anomalne wartości SL przedstawia się niekiedy punktowo na tle map wytrzymałości podłoża (El Hamdouni i in. 2008, Dehbozorgi i in. 2010, Alipoor i in. 2011). Anomalnie wysokie wartości wskaźnika w obszarach o względnie jednorodnych cechach podłoża odzwierciedlają najpewniej wpływ wypiętrzania tektonicznego, podczas gdy wartości anomalnie niskie mogą wskazywać na odcinki, w których rzeka zakłada swą dolinę w strefie młodych uskoków przesuwczych (Keller, Pinter 1996).

Uzyskane wyniki często prezentowano w postaci wykresów (Guarnieri, Pirrotta 2008, El Hamdouni i in. 2008, García-Tortosa i in. 2008, Pedrera i in. 2009, Dehbozorgi $i$ in. 2010) lub też przedstawiano na mapach, przyjmując jedną z trzech metod graficznej prezentacji: punktową (Peters, van Balen 2007, Antón i in. 2014), liniową (El Hamdouni i in. 2008, Dehbozorgi i in. 2010, Alipoor $\mathrm{i}$ in. 2011) lub powierzchniową (Ranoszek 2001, Forma, Zuchiewicz 2002, Zuchiewicz 2010, Troiani, Della Seta 2008, Tsodoulos i in. 2008). Niekiedy mapy przestawiające zróżnicowanie wartości wskaźnika w sposób powierzchniowy odnosiły się do znormalizowanych jego wartości (Pedrera i in. 2009, Pérez-Peña i in. 2009, Azañón i in. 2012), które interpolowano przy użyciu metod geostatystycznych. Rzadko stosowanym podejściem było natomiast obliczanie wartości wskaźnika SL jako średnich dla poszczególnych zlewni przy okazji obliczania innych parametrów, w większości bezpośrednio odnoszących się do cech geometrycznych i wysokościowych zlewni, na potrzeby utworzenia syntetycznego wskaźnika względnej aktywności tektonicznej (Dehbozorgi i in. 2010, Alipoor i in. 2011).

Burbank i Anderson (2011) podkreślają, że rozwój cyfrowych modeli wysokościowych oraz narzędzi GIS przyczynił się do zastępowania wskaźnika długości spadku rzeki, początkowo obliczanego w oparciu o mapy topograficzne, wskaźnikiem stromości (termin dotąd nieobecny w literaturze polskiej, autorska propozycja nazwy za ang. steepness index) (Snyder i in. 2000, Kirby, Whipple 2001, Wobus i in. 2006a, b) obliczanym z równania prawa potęgowego (ang. power-law):

$$
\mathrm{S}=\mathrm{k}_{\mathrm{s}} \mathrm{A}^{-\theta}
$$

gdzie:

$\mathrm{S}$ - lokalny spadek cieku,

$\mathrm{k}_{\mathrm{s}}$ - indeks stromości, 
A - powierzchnia zlewni liczona w górę cieku (od punktu środkowego badanego odcinka),

$\theta$ - indeks wklęsłości.

Indeks wklęsłości $\theta$ odnosi się do profilu podłużnego cieku i obliczany jest najczęściej na podstawie punktowych wykresów typu log-log, z wartościami A na osi odciętych oraz S na osi rzędnych, przy zastosowaniu równań regresji liniowej w środowisku Matlab (por. np. Duvall $i$ in. 2004, VanLaningham i in. 2006). Jego wartości mieszczą się zasadniczo w przedziale 0,4-0,7 (Whipple 2004). Wyższe wartości indeksu stromości wskazują generalnie na większe tempo dźwigania tektonicznego, jednak i w tym przypadku duży wpływ na wartość indeksu ma zróżnicowanie litologiczne, a przez to i wytrzymałościowe, podłoża.

Porównywanie różnych cieków pod kątem wskaźnika stromości wymaga znormalizowania uzyskanych wartości poprzez zastosowanie tzw. wklęsłości referencyjnej, w większości prac określanej na poziomie 0,45 (Snyder $i$ in. 2000, Wobus i in. 2006a, b, Castillo i in. 2014, Flores-Prieto $\mathrm{i}$ in. 2015). Wskaźnik ten nie był do tej pory wykorzystywany $\mathrm{w}$ badaniach morfotektonicznych prowadzonych przez polskich autorów.

\section{Uwagi końcowe}

Współczesne badania morfotektoniczne bazują na wskaźnikach morfometrycznych wprowadzonych do literatury w minionych dekadach, a na tym tle wyróżnia się jedynie indeks stromości wykorzystywany w tego typu badaniach od niedawna (np. Wobus i in. 2006a, b, Castillo i in. 2014). W większości są to wskaźniki opracowane pierwotnie dla potrzeb badań hydrologicznych, które zostały następnie przeniesione na grunt geomorfologii tektonicznej i zaaplikowane do wykrywania oznak mobilności tektonicznej podłoża. Dobrym przykładem jest wskaźnik krętości obliczany początkowo dla koryt rzecznych (Brice 1964), później zaś wykorzystywany do określania cech morfologicznych frontów górskich i dokonywania na tej podstawie oceny stopnia ich aktywności (Bull 1977, Bull, McFadden 1977). Podobna sytuacja dotyczy większości wskaźników charakteryzujących zlewnie oraz odnoszących się do cech systemu rzecznego.

W przeważającej większości prac stopień aktywności tektonicznej obszarów określano w oparciu o większą liczbę wskaźników, wprowadzając niekiedy miary o charakterze syntetycznym, tworzone na podstawie wyników uzyskanych z obliczania poszczególnych wskaźników cząstkowych (El Hamdouni i in. 2008, Brzezińska-Wójcik 2013, Chabudziński, Brzezińska-Wójcik 2013). Stosowanie dużej liczby wskaźników pozwoliło autorom na badanie stopnia ich korelacji (Ranoszek 2001, Badura i in. 2003, Zuchiewicz 2010).

Przez lata zmieniły się źródła danych i narzędzia, które pozwoliły na usprawnienie prowadzonych obliczeń oraz wykrywanie związków i relacji przestrzennych pomiędzy cechami rzeźby (Jordan 2003, Jordan i in. 2003).
Rozwój środowiska GIS, zastąpienie map topograficznych cyfrowymi modelami wysokości i udostępnianie danych wysokościowych o coraz wyższej jakości otworzyło nowe możliwości i kierunki badawcze, stwarzając także możliwość reinterpretacji uzyskanych wcześniej wyników. Obserwuje się jednocześnie stale postępujący rozwój w dziedzinie narzędzi komputerowych tworzonych specjalnie dla potrzeb badań morfotektonicznych (Shahzad, Gloaguen 2011a, b, Chabudziński, Brzezińska-Wójcik 2013, Daxberger i in. 2014).

Narzędzia te pozwalają na wykrycie obszarów rozwijających się przypuszczalnie w warunkach aktywnej tektoniki, tym niemniej wpływ innych uwarunkowań w tego typu analizach musi być brany pod uwagę. Morfologia frontów górskich, geometria dolin rzecznych, kształt i asymetria zlewni, cechy systemu rzecznego oraz spadek cieków, do których odnoszą się omówione w niniejszej pracy wskaźniki, są bowiem w dużej mierze zależne od czynników pozatektonicznych, w tym głównie litologicznych, strukturalnych oraz klimatycznych. W ten sposób porównywalność wyników uzyskiwanych dla obszarów o odmiennych uwarunkowaniach przyrodniczych może być znacząco ograniczona.

\section{Podziękowania}

Składam serdeczne podziękowania Piotrowi Migoniowi za cenne uwagi do pierwszej wersji artykułu oraz recenzentom za pomoc w jego udoskonaleniu. Praca powstała w ramach działalności statutowej Instytutu Geografii i Rozwoju Regionalnego Uniwersytetu Wrocławskiego (nr 1015/S/2015).

\section{Literatura}

Alipoor R., Poorkermani M., Zare M., El Hamdouni R., 2011. Active tectonic assessment around Rudbar Lorestan dam site, High Zagros Belt (SW of Iran). Geomorphology 128: 1-14, DOI: http://dx.doi. org/10.1016/j.geomorph.2010.10.014.

Al-Taj M., Shakour F., Atallah M., 2007. Morphotectonic indices of the Dead Sea Transform, Jordan. Geografia Fisica e Dinamica Quaternaria 30: 5-11.

Altın T.B., 2012. Geomorphic signatures of active tectonic in drainage basins in the southern Bolkar Mountain, Turkey. Indian Society of Remote Sensing 40: 271-285, DOI: http://dx.doi.org/10.1007/ s12524-011-0145-8.

Antón L., De Vicente G., Muñoz-Martín A., Stokes M., 2014. Using river long profiles and geomorphic indices to evaluate the geomorphological signature of continental scale drainage capture, Duero basin (NW Iberia). Geomorphology 206: 250-261, DOI: http://dx.doi. org/10.1016/j.geomorph.2013.09.028.

Ata H.A., 2008. A test of the validity of morphometric analysis in determining tectonic activity from ASTER derived DEMs in the Jordan-Dead Sea Transform Zone. University of Arkansas, rozprawa doktorska, Online: http://cast.uark.edu/assets/files/PDF/HUSAMATA_Final_Dissertation_Complete.pdf - 26.07.2015.

Avena G.C., Giuliano G., Lupia Palmieri E., 1967. Sulla valutazione quantitativa Della gerarchizzazione ed evoluzione dei reticoli fluviali. Bollettino della Società Geologica Italiana 86(4): 781-796.

Azañón J.M., Pérez-Peña J.V., Giaconia F., Booth-Rea G., MartínezMartínez J.M., Rodríguez-Peces M.J., 2012. Active tectonics in the central and eastern Betic Cordillera through morphotectonic 
analysis: the case of Sierra Nevada and Sierra Alhamilla. Journal of Iberian Geology 38(1): 225-238, DOI: http://dx.doi.org/10.5209/ rev JIGE.2012.v38.n1.39214.

Badura J., Zuchiewicz W., Górecki A., Sroka W., Przybylski B., 2003. Morfometria strefy sudeckiego uskoku brzeżnego między Złotym Stokiem a Dobromierzem. Przegląd Geologiczny 51(12): 1048-1057.

Badura J., Zuchiewicz W., Štěpančíková P., Przybylski B., Kontny B., Cacoń S., 2007. The Sudetic Marginal Fault: A young morphotectonic feature at the NE margin of the Bohemian Massif, Central Europe. Acta Geodynamica et Geomaterialia 4(4): 7-29.

Badura J., Zuchiewicz W., Štěpančíková P., Tokarski A. K., Świerczewska A., Przybylski B., 2008. Strefa sudeckiego uskoku brzeżnego w świetle wyników badań morfotektonicznych i analizy spękanych klastów w osadach czwartorzędowych. Abstrakty, Pierwszy Polski Kongres Geologiczny, Kraków 26-28 czerwca 2008, Polskie Towarzystwo Geologiczne, Kraków: 7-8.

Bafti A.S., 2009. Tectonics movements of Kuhbanan fault system in Bahabad region, Central Iran. Iranian Journal of Earth Sciences 1: 92-98.

Bahrami S., 2013. Analyzing the drainage system anomaly of Zagros basins: Implications for active tectonics. Tectonophysics 608: 914-928, DOI: http://dx.doi.org/10.1016/j.tecto.2013.07.026.

Brice J.C., 1964. Channel patterns and terraces of the Loup River, Nebraska. U.S. Geological Survey Professional Paper 422-D.

Brzezińska-Wójcik T., 2002. The dependence of relief on tectonics in the South-West Escarpment Zone of Tomaszowskie Roztocze (SE Poland). Landform Analysis 3: 13-24.

Brzezińska-Wójcik T., 2013. Morfotektonika w annopolsko-lwowskim segmencie pasa wyżynnego w świetle analizy cyfrowego modelu wysokościowego oraz wskaźników morfometrycznych. Wydawnictwo Uniwersytetu Marii Curie-Skłodowskiej, Lublin.

Brzezińska-Wójcik T., Hołub B., 2007. Przejawy neogeńskiej tektoniki w przełomowym odcinku doliny Sopotu w strefie krawedziowej Roztocza Tomaszowskiego. W: M. Harasimiuk, T. Brzezińska-Wójcik, R. Dobrowolski, P. Mroczek, J. Warowna (red.), Budowa geologiczna regionu lubelskiego i problemy ochrony litosfery. Wydawnictwo Uniwersytetu Marii Curie-Skłodowskiej, Lublin: 153-165.

Brzezińska-Wójcik T., Miłkowska D., Tucki A., 2002. Wpływ neotektoniki na rozwój rzeźby w dorzeczu Gorajca na Roztoczu (SE Polska). Annales Universitatis Mariae Curie-Skłodowska Lublin - Polonia, Sectio B 54(4): 55-74.

Brzezińska-Wójcik T., Chabudziński Ł., Gawrysiak L., 2010 a. Neotectonic mobility of the Roztocze region, Ukrainian part, Central Europe: insights from morphometric studies. Annales Societatis Geologorum Poloniae 80: 167-183.

Brzezińska-Wójcik T., Gawrysiak L., Chabudziński Ł., 2010 b. Metody morfometryczne w badaniach geomorfologicznych regionu lubelskiego. Landform Analysis 12: 7-22.

Bull W.B., 1977. Tectonic geomorphology of the Mojave Desert. U.S. Geological Survey Contract Report 14-08-001-G-394, Office of Earthquakes, Volcanoes and Engineering, Menlo Park, California.

Bull W.B., 1978. Geomorphic tectonic activity classes of the south front of the San Gabriel Mountains, California. U.S. Geological Survey Contract Report 14-08-001-G-394, Office of Earthquakes, Volcanoes and Engineering, Menlo Park, California.

Bull W.B., 2007. Tectonic Geomorphology of Mountains: A New Approach to Paleoseismology. Blackwell Publishing.

Bull W.B., McFadden L.D., 1977. Tectonic geomorphology north and south of the Garlock Fault, California. W: D. O. Doehring (red.), Geomorphology in Arid Regions. Proceedings of the $8^{\text {th }}$ Annual Geomorphology Symposium, State University of New York at Binghamton: $115-138$.

Burbank D.W., Anderson R.S., 2001. Tectonic Geomorphology. Blackwell Science.

Burbank D.W., Anderson R.S., 2011. Tectonic Geomorphology (2 $2^{\text {nd }}$ ed.). Wiley-Blackwell.

Cannon P.J., 1976. Generation of explicite parameter for a quantitative geomorphic study of the Mill Creek drainage basin. Oklahoma Geology Notes 36(1): 3-16.

Castillo M., Muñoz-Salinas E., Ferrari L., 2014. Response of a landscape to tectonics using channel steepness indices $\left(\mathrm{k}_{\mathrm{sp}}\right)$ and OSL: A case of study from the Jalisco Block, Western Mexico. Geomorphology 221: 204-214, DOI: http://dx.doi.org/10.1016/j.geomorph.2014.06.017.

Chabudziński Ł., Brzezińska-Wójcik T., 2013. Zastosowanie ArcNEO do oceny przejawów neotektoniki na przykładzie zlewni górnego Wieprza (Roztocze, środkowo-wschodnia Polska). Landform Analysis 24: 11-22, DOI: http://dx.doi.org/10.12657/landfana.024.002.

Chen Y., Sung Q., Cheng K., 2003. Along-strike variations of morphotectonic features in the Western Foothills of Taiwan: tectonic implications based on stream-gradient and hypsometric analysis. Geomorphology 56: 109-137, DOI: http://dx.doi.org/10.1016/S0169555X(03)00059-X.

Chorley R.L., 1957. Climate and morphometry. Journal of Geology 65(6): 628-638.

Cox R.T., 1994. Analysis of drainage basin symmetry as a rapid technique to identify areas of possible Quaternary tilt-block tectonics: an example form the Mississippi Embayment. Geological Society of America Bulletin 106: 571-581.

Cuong N.Q., Zuchiewicz W., 2001a. Morphotectonic properties of the Lo River Fault near Tam Dao in North Vietnam. Natural Hazards and Earth System Sciences 1: 15-22.

Cuong N.G., Zuchiewicz W., 2001b. Morfotektonika uskoku rzeki Lo w rejonie Tam Dao (północny Wietnam): próba prognozy sejsmicznej. Przegląd Geologiczny 49(10): 885-893.

Dar R.A., Romshoo S.A., Chandra R., Ahmad I., 2014. Tectono-geomorphic study of the Karewa Basin of Kashmir Valley. Journal of Asian Earth Sciences 92: 143-156, DOI: http://dx.doi.org/10.1016/j. seaes.2014.06.018.

Daxberger H., Dalumpines R., Scott D.M., Riller U., 2014. The ValleyMorph Tool: An automated extraction tool for transverse topographic symmetry $(\mathrm{T}-$ ) factor and valley width to valley height (Vf-) ratio. Computers \& Geosciences 70: 154-163, DOI: http://dx.doi. org/10.1016/j.cageo.2014.05.015

Dehbozorgi M., Pourkermani M., Arian M., Matkan A.A., Motamedi H., Hosseiniasl A., 2010. Quantitative analysis of relative tectonic activity in the Sarvestan area, central Zagros, Iran. Geomorphology 121: 329-341, DOI: http://dx.doi.org/10.1016/j.geomorph.2010.05.002.

Delcaillau B., Amrhar M., Namous M., Laville E., 2008. Transpressional tectonics in the Marrakech High Atlas: Insight by the geomorphic evolution of drainage basins. Geomorphology 134: 344-362, DOI: http://dx.doi.org/10.1016/j.geomorph.2011.07.010.

Duvall A., Kirby E., Burbank D., 2004. Tectonic and lithologic controls on bedrock channel profiles and processes in costal California. Journal of Geophysical Research 109, DOI: http://dx.doi.org/10.1029/ 2003JF000086.

El Hamdouni R., Irigaray C., Fernandez T., Chacón J., Keller E. A., 2008. Assessment of relative active tectonics, southwest border of Sierra Nevada (southern Spain). Geomorphology 96: 150-173, DOI: http://dx.doi.org/10.1016/j.geomorph.2007.08.004.

Engstrom W.N., 1989. Morphometric analysis of mountain drainage basins in the Basin and Range Province, USA. Zeitschrift für Geomorphologie N. F. 33: 443-453.

Figueroa A.M., Knott J.R., 2010. Tectonic geomorphology of the southern Sierra Nevada Mountains (California): Evidence for uplift and basin formation. Geomorphology 123: 34-45, DOI: http://dx.doi. org/10.1016/j.geomorph.2010.06.009.

Flores-Prieto E., Quénéhervé G., Bachofer F., Shahzad F., Maerker M., 2015. Morphotectonic interpretation of the Makuyuni catchment in the Northern Tanzania using DEM and SAR data. Geomorphology 248: 427-439, DOI: http://dx.doi.org/10.1016/j.geomorph.2015.07.049.

Forestier G., Wemmert C., Gancarski P., 2008. Collaborative multi-strategical clustering for object-oriented image analysis. W: O.Okun, G.Valentini (red.), Supervised and unsupervised ensemble methods and their applications. Springer-Verlag, Berlin Heidelberg: 71-90.

Forma A., Zuchiewicz W., 2002. Morphotectonics of the Gorce Mountains, Western Outer Carpathians. Folia Quaternaria 73: 69-78.

Gao M., Zeilinger G., Xu X., Wang Q., Hao M., 2013. DEM and GIS analysis of geomorphic indices for evaluating recent uplift of the northeastern margin of the Tibetan Plateau, China. Geomorphology 190: 61-72, DOI: http://dx.doi.org/10.1016/j.geomorph.2013.02.008.

García-Tortosa F.J., Alfaro P., Galindo-Zaldívar J., Gibert L., López-Garrido A.C., Sanz de Galdeano C., Ureña M., 2008. Geomorphologic evidence of the active Baza Fault (Betic Cordillera, South Spain). 
Geomorphology 97: 374-391, DOI: http://dx.doi.org/10.1016/j.geomorph.2007.08.007.

Guarnieri P., Pirrotta C., 2008. The response of drainage basins to the late Quaternary tectonics in the Sicilian side of the Messina Strait (NE Sicily). Geomorphology 95: 260-273, DOI: http://dx.doi. org/10.1016/j.geomorph.2007.06.013.

Gürbüz A., Gürer Ö. F., 2008. Tectonic geomorphology of the North Anatolian Fault Zone in the Lake Sapanca basin (aastern Marmara region, Turkey). Geosciences Journal 12(3): 215-225, DOI: http:// dx.doi.org/10.1007/s12303-008-0022-9.

Hack J.T., 1973. Stream-profile analysis and stream-gradient index. U. S. Geological Survey Journal of Research 1: 421-429.

Hare P.W., Gardner T.W., 1985. Geomorphic indicators of vertical neotectonism along converging plate margins, Nicoya Peninsula, Costa Rica. W: M.Morisawa, J.T.Hack (red.), Tectonic Geomorphology. Proceedings of the $15^{\text {th }}$ Annual Binghamton Geomorphology Symposium, September 1984, Boston: 76-104.

Horton R.E., 1932. Drainage basin characteristics. Transactions, American Geophysical Union 13(1): 350-361.

Horton R.E., 1945. Erosional development of streams and their drainage basins; hydrophysical approach to quantitative morphology. Bulletin of the Geological Society of America 56: 275-370.

Hovius N., 1996. Regular spacing of drainage outlets from linear mountain belts. Basin Research 8:29-44

Jami M., Mousavi E.J., Hadizadeh A., Pourkermani M., 2013. The evaluation of Saravan Fault Activities in Iran on the Basis of Geomorphologic Evidences. Indian Journal of Science and Technology 6(4): 4362-4367.

Jamieson S.S.R., Sinclair H.D., Kirstein L.A., Purves R.S., 2004. Tectonic forcing of longitudinal valleys in the Himalaya: morphological analysis of the Ladakh Batholith, North India. Geomorphology 58: 49-65, DOI: http://dx.doi.org/10.1016/S0169-555X(03)00185-5.

Jayappa K.S., Markose V.J., Nagaraju M., 2012. Identification of geomorphic signatures of neotectonics activity using DEM in the Precambrian terrain of Western Ghats, India. International Archives of the Photogrammetry, Remote Sensing and Spatial Information Sciences 39-B8, XXII ISPRS Congress, 25 August - 01 September, Melbourne, Australia.

Jordan G., 2003. Morphometric analysis and tectonic interpretation of digital terrain data: a case study. Earth Surface Processes and Landforms 28(8): 807-822, DOI: http://dx.doi.org/10.1002/esp.469.

Jordan G., Csillag G., Szucs A., Qvarfort U., 2003. Application of digital terrain modelling and GIS methods for the morphotectonic investigation of the Kali Basin, Hungary. Zeitschrift für Geomorphologie N. F. 47: 145-169.

Kale V. S., Shejwalkar N., 2008. Uplift along the western margin of the Deccan Basalt Province: Is there any geomorphometric evidence? Journal of Earth System Science 117: 959-971.

Keller E., Pinter N., 1996. Active Tectonics. Earthquake, Uplift, and Landscape. Prentice Hall, Upper Saddle River, New Jersey.

Keller E., Pinter N., 2002. Active Tectonics. Earthquake, Uplift, and Landscape ( $2^{\text {nd }}$ ed.). Prentice Hall, Upper Saddle River, New Jersey.

Khadri S.F.R., Kharbadkar V.S., 2013. Morphometric Analysis of the Vidarbha River Basin, Amravati District, Maharashtra with Reference to Watershed Management. Golden Research Thoughts 3(3).

Khalaj M., 2015. Morphotectonic Analysis of Burkh Anticline, North of Bastak (Iran). Open Journal of Geology 5: 387-393, DOI: http:// dx.doi,org/10.4236/ojg.2015.56036.

Kirby E., Whipple K., 2001. Quantifying differential rock-uplift rates via stream profile analysis. Geology 29(5): 415-418.

Kouli M., Vallianatos F., Soupios P., Alexakis D., 2006. A GIS example of morphometric analysis in tectonic structures of Western Crete, Greece. Proceedings of the $5^{\text {th }}$ WSEAS International Conference on Environment, Ecosystems and Development, Venice, Italy, November 20-22: 229-234.

Krzyszkowski D., Migoń P., Sroka W., 1995. Neotectonics Quaternary history of the Sudetic Marginal Fault, SW Poland. Folia Quaternaria 66: 73-98.

Lykoudi E., Angelaki M., 2004. The contribution of the morphometric parameters of an hydrographic network to the investigation of the neotectonics activity: an application to the upper Acheloos river. Bul- letin of the Geological Society of Greece, Proceedings of the 10th International Congress, Thessaloniki: 1084-1092.

Mahmood S.A., Gloaguen R., 2012. Appraisal of active tectonics in Hindu Kush: Insights from DEM derived geomorphic indices and drainage analysis. Geoscience Frontiers 3: 407-428., DOI: http://dx.doi. org/10.1016/j.gsf.2011.12.002.

Malik J.N., Mohanty C., 2007. Active tectonic influence on the evolution of drainage and landscape: Geomorphic signatures from frontal and hinterland areas along the Northwestern Himalaya, India. Journal of Asian Earth Sciences 29: 604-618, DOI: http://dx.doi.org/10.1016/j. jseaes.2006.03.010.

Matsuda I., 2004. River morphology and channel processes. W: J. C. I. Dooge (red.), Fresh Surface Water, Encyklopedia of Life Suport Systems, Eolss Publishers, Oxford, Online: http://www.eolss.net/ebooks/ Sample\%20Chapters/C07/E2-07-02-01.pdf - 26.07.2015.

Mayer L., 1986. Tectonic geomorphology of escarpments and mountain fronts. W: Active Tectonics. National Academy Press, Washington: $125-135$.

Melosh B.L., Keller E.A., 2013. Effects of active folding and reverse faulting on stream channel evolution, Santa Barbara Fold Belt, California. Geomorphology 186: 119-135, DOI: http://dx.doi. org/10.1016/j.geomorph.2012.12.027.

Melton M.A., 1957. An analysis of the relation among elements of climate, surface properties and Geomorphology. ONR Technical Report 11. Columbia University, New York.

Melton M.A., 1958. Correlation structure of morphometric properties of drainage systems and their controlling agents. Journal of Geology 66: $442-460$.

Migoń P., Zwiernik M., 2006. Strukturalne uwarunkowania rzeźby północno-wschodniego progu Gór Stołowych. Przegląd Geograficzny 78(3): 319-338.

Miller V.C., 1953. Quantitative geomorphological study of drainage basin characteristics in the Clinch Mountain area, Virginia and Tennessee. ONR Technical Report 3. Columbia University, New York.

Neumann L., 1900. Die Dichte des Flussnetzes im Schwarzwalde. Gerlands Beiträge zur Geophysik 4(3): 219-240.

Omidali M., Arian M., Sorbi A., 2015. Neotectonics of Boroujerd Area, SW Iran by Index of Active Tectonics. Open Journal of Geology 5: 309-324, DOI: http://dx.doi.org/10.4236/ojg.2015.55028.

Pánek T., 2004. The use of morphometric parameters in tectonic geomorphology (of the example of the Western Beskidy Mts). Acta Universitatis Carolinae, Geographica 1: 111-126.

Pedrera A., Pérez-Peña J. V., Galindo-Zaldívar J., Azañón J. M., Azor A., 2009. Testing the sensitivity of geomorphic indices in areas of low-rate active folding (eastern Betic Cordillera, Spain). Geomorphology 105: 218-231, DOI: http://dx.doi.org/10.1016/j.geomorph.2008.09.026.

Pérez-Peña J.V, Azañón J.M., Azor A., Delgado J., González-Lodeiro F., 2009. Spatial analysis of stream power using GIS: SLk anomaly maps. Earth Surface Processes and Landforms 34(1): 16-25, DOI: http://dx.doi.org/10.1002/esp.1684.

Pérez-Peña J.V., Azor A., Azañón J. M., Keller E. A., 2010. Active tectonics in the Sierra Nevada (Betic Cordillera, SE Spain): Insights from geomorphic indexes and drainage pattern analysis. Geomorphology 119: 74-87, DOI: http://dx.doi.org/10.1016/j.geomorph.2010.02.020.

Peters G., van Balen R.T., 2007. Tectonic geomorphology of the northern Upper Rhine Graben, Germany. Global and Planetary Change 58: 310 - 334, DOI: http://dx.doi.org/10.1016/j.gloplacha.2006.11.041.

Raj R., 2012. Active tectonics of the Gujarat (India) by morphometric and morphostructural studies of Vatrak River basin. Journal of Asian Earth Sciences 50: 66-78, DOI: http://dx.doi.org/10.1016/j. jseaes.2012.01.010

Ramesth M.H., Mohammadabadi T.M., Pourkhosravani M., Mousavi S.H., 2011. Assessment of morphotectonic properties of Mahan Tigrani watershed. Management Science Letters 1: 503-510, DOI: http:// dx.doi.org/10.5267/j.ms1.2011.06.013.

Ramírez-Herrera M.T., 1998. Geomorphic assessment of active tectonics in the Acambay graben, Mexican Volcanic Belt. Earth Surface Processess and Landforms 23: 317-332.

Ranoszek W., 2001. Krawędzie morfologiczne o genezie tektonicznej w Sudetach w świetle pomiarów ilościowych. Uniwersytet Wrocławski, rozprawa doktorska. 
Rockwell T.K., Keller E.A., Johnson D.L., 1985. Tectonic geomorphology of alluvial fans and mountain fronts near Ventura, California. W: M. Morisawa, T. J. Hack (red.), Tectonic Geomorphology, Proceedings of the $15^{\text {th }}$ Annual Binghamton Geomorphology Symposium, September 1984, Boston: 183-207.

Saberi M.R., Pourkermani M., Nadimi A., Ghorashi M., Asadi A., 2014. Geomorphic Assessment of Active Tectonics in Tozlogol Basin, Sanandaj-Sirjan Zone, Iran. Current Trends in Technology and Science 3(3): 146-154.

Sahebari S.S., Ghorashi M., Nazari H., Sattarzadeh Y., 2015. Evaluation of Active Tectonics of "Talkheh Rud" Basin Using Geomorphological Indices. Advances in Environmental Biology 9: 424-433.

Samadi H.R., 2014. Tectonics Movements Fault System of Central Iran. World Applied Sciences Journal 32(9): 1835-1840, DOI: http://dx. doi.org/10.5829/idosi.wasj.2014.32.09.86

Sarp G., Gecen R., Toprak V., Duzgun S., 2011. Morphotectonic Properties of Yenicaga Basin Area in Turkey. 34 ${ }^{\text {th }}$ International Symposium on Remote Sensing of Environment (ISRSE34), Online: http://www. isprs.org/proceedings/2011/ISRSE-34/211104015Final00629.pdf 26.07.2015.

Schumm S.A., 1954. Evolution of drainage systems and slopes in badlands at Perth Amboy, New Jersey. ONR Technical Report 8. Columbia University, New York.

Schumm S.A., 1956. Evolution of drainage systems and slopes in badlands at Perth Amboy, New Jersey. Geological Society of America Bulletin 67(5): 597-646.

Shahzad F., Gloaguen R., 2011a. TecDEM: A MATLAB based toolbox for tectonic geomorphology, Part 1: Drainage network processing and stream profile analysis. Computers \& Geosciences 37(2): 250-260, DOI: http://dx.doi.org/10.1016/j.cageo.2010.06.008

Shahzad F., Gloaguen R., 2011a. TecDEM: A MATLAB based toolbox for tectonic geomorphology, Part 2: Surface dynamics and basin analysis. Computers \& Geosciences 37(2): 261-271, DOI: http://dx.doi. org/10.1016/j.cageo.2010.06.009

Shtober-Zisu N., Greenbaum N., Inbar M., Flexer A., 2008. Morphometric and geomorphic approaches for assessment of tectonic activity, Dead Sea Rift (Israel). Geomorphology 102: 93-104, DOI: http:// dx.doi.org/10.1016/j.geomorph.2007.06.017.

Shukla D.P., Dubey C.S., Ningreichon A.S., Singh R.P., Mishra B.K., Singh S.K., 2014. GIS-based morpho-tectonic studies of Alaknanda river basin: a precursor for hazard zonation. Natural Hazards 71: 1433-1452, DOI: http://dx.doi.org/10.1007/s11069-013-0953-y.

Silva P.G., Goy J.L., Zazo C., Bardají T., 2003. Fault-generated mountain fronts in southeast Spain: geomorphologic assessment of tectonic and seismic activity. Geomorphology 50: 203-225.

Simoni A., Elmi C., Picotti V., 2003. Late Quaternary uplift and valley evolution in the Northern Apennines: Lamone catchment. Quaternary International 101-102: 253-267.

Singh V.P., 1988. Hydrologic Systems: Vol. 1. Rainfall-runoff Modeling. Prentice Hall.

Singh T., Virdi N.S., 2007. Tectonic activity classes along the Nahan Thrust (NT) in NW Sub-Himalaya. Journal of the Indian Society of Remote Sensing 35(3): 229-238, DOI: http://dx.doi.org/10.1007/ BF03013490.

Snyder N.P., Whipple K.X., Tucker G.E., Merritts D.J., 2000. Landscape response to tectonic forcing: Digital elevation model analysis of stream profiles in the Mendocino triple junction region, northern California. Bulletin of the Geological Society of America 112(8): $1250-1263$.

Sroka W., 1997. Ewolucja morfotektoniczna Sudetów w rejonie Kotliny Kłodzkiej w świetle analizy morfometryczno-statystycznej. Prace Geologiczno-Mineralogiczne LVIII, Acta Universitatis Wratislaviensis, Wydawnictwo Uniwersytetu Wrocławskiego, Wrocław.

Štěpančíková P., Stemberk J., Vilímek V., Košták B., 2008. Neotectonic development of drainage network in the East Sudeten and monitoring of recent displacements on tectonic structures (Czech Republic). Geomorphology 102: 68-80, DOI: http://dx.doi.org/10.1016/j.geomorph.2007.06.016.

Strahler A.N., 1952. Hypsometric (area-altitude) analysis of erosional topography. Bulletin of the Geological Society of America 63(11): $1117-1142$
Talling P.J., Steward M.D., Stark C.P., Gupta S., Vincent S. J., 1997. Regular spacing of drainage outlets from linear fault blocks. Basin Research 9: 275-302.

Toudeshki V.H., Arian M., 2011. Morphotectonic analysis in the Ghezel Ozan river basin, NW Iran. Journal of Geography and Geology 3(1): 258-265, DOI: http://dx.doi.org/10.5539/jgg.v3n1p258.

Troiani F., Dell Seta M., 2008. The use of the Stream-Gradient index in morphotectonic analysis of small catchments: A case study from Central Italy. Geomorphology 102: 159-168, DOI: http://dx.doi. org/10.1016/j.geomorph.2007.06.020

Tsodoulos I.M., Koukouvelas I.K., Pavlides S., 2008. Tectonic geomorphology of the easternmost extension of the Gulf of Corinth (Beotia, Central Greece). Tectonophysics 453: 211-232, DOI: http://dx.doi. org/10.1016/j.tecto.2007.06.015.

VanLaningham S., Meigs A., Goldfinger C., 2006. The effects of rock uplift and rock resistance on river morphology in a subduction zone forearc, Oregon, USA. Earth Surface Processes and Landforms 31(10): 1257-1279, DOI: http://dx.doi.org/10.1002/esp.1326.

Verrios S., Zygouri V., Kokkalas S., 2004. Morphotectonic analysis in the Eliki fault zone (Gulf of Corinth, Greece). Bulletin of the Geological Society of Greece, Proceedings of the 10th International Congress, Thessaloniki: 1706-1715.

Vojtko R., Beták J., Hók J., Marko F., Gajdoš V., Rozimant K., Mojzeš A., 2011a. Pliocene to Quaternary tectonics in the Horná Nitra Depression (Western Carpathians). Geologica Carpathica 62(4): 381393, DOI: http://dx.doi.org/10.2478/v10096-011-0028-5.

Vojtko R., Marko F., Preusser F., Madras J., Kováčová M., 2011b. Late Quaternary fault activity in the Western Carpathians: evidence from Vikartovce Fault (Slovakia). Geologica Carpathica 62(6): 563-574, DOI: 10.2478/v10096-011-0040-9.

Wallace R.E., 1978. Geometry and rates of change of fault-generated range front, north-central Nevada. Journal of Research of the United States Geological Survey 6: 637-650.

Wobus C., Whipple K.X., Kirby E., Snyder N., Johnson J., Spyropolou K., Crosby B., Sheehan D., 2006a. Tectonics from topography: Procedures, promise, and pitfalls. W: S.D.Willet, N.Hovius, M.T.Brandon, D.Fisher (red.), Tectonics, Climate and Landscape Evolution. Geological Society of America, Special Paper 398: 55-74.

Wobus C., Crosby B.T., Whipple K.X., 2006b. Hanging valleys in fluvial systems: Controls on occurrence and implications for landscape evolution. Journal of Geophysical Research 111, F02017, DOI: http:// dx.doi.org/10.1019/2005JF000406.

Wells S.G., Bullard T.F., Menges C.M., Drake P.G., Karas P.A., Kelson K.I., Ritter J.B., Wesling J.R., 1988. Regional variations in tectonic geomorphology along a segmented convergent plate boundary pacific coast of Costa Rica. Geomorphology 1: 239-265.

Whipple K.X., 2004. Bedrock rivers and the geomorphology of active orogens. Annual Review of Earth and Planetary Science 32: 151-185. DOI: 10.1146/annurev.earth.32.101802.120356

Wieczorek M., Żyszkowska W., 2011. Geomorfometria - parametry morfometryczne w charakterystyce rzeźby terenu. Polski Przegląd Kartograficzny 43 (2): 130-144.

Wiwegwin W., Sugiyama Y., Hisada K., Charusiri P., 2011. Re-evaluation of the activity of the Thoen Fault in the Lampang Basin, northern Thailand, based on geomorphology and geochronology. Earth, Planets and Space 63: 975-990. DOI: http://dx.doi.org/10.5047/ eps.2011.06.018.

Zăvoianu I., 1985. Morphometry of Drainage Basin. Developments in Water Science 20, Elsevier, Bukareszt.

Zavoili E., Konstantinidi E., Koukouvelas I. K., 2004. Tectonic geomorphology of escarpments: the cases of Kompotades and Nea Anchialos faults. Bulletin of the Geological Society of Greece 36: 1716-1725.

Zuchiewicz W., 1980. Analiza morfometryczno-statystyczna małych zlewni w obszarach mobilnych tektonicznie. Czasopismo Geograficzne 51: 171-185.

Zuchiewicz W., 1989. Morphotectonic phenomena in the Polish Flysch Carpathians: a case study of the Eastern Beskid Niski Mountains. Quaestiones Geographicae, Special Issue 2: 155-167.

Zuchiewicz W., 1995. Neotectonic tendencies in the Polish Outer Carpathians in the light of some river valley parameters. Studia Studia Geomorphologica Carpatho-Balcanica 29: 55-76. 
Zuchiewicz W., 2000. Morphotectonics of the Outer East Carpathians of Poland in the light of cartometric studies. Studia Geomorphologica Carpatho-Balcanica 34: 5-26.

Zuchiewicz W., 2010. Neotektonika Karpat polskich i zapadliska przedkarpackiego. Wydawnictwa AGH, Kraków.
Zuchiewicz W., McCalpin J. P., 2000. Geometry of faceted spurt on an active normal fault: case study of the central Wasatch fault, Utah, U.S.A. Annales Societatis Geologorum Poloniae 70: 231-249.

Zwoliński Z., 2010. O homologiczności polskiej terminologii geoinformacyjnej. W: Z. Zwoliński (red.), GIS - woda w środowisku. Bogucki Wydawnictwo Naukowe, Poznań: 21-30. 